\title{
Christ and Charon: PGM P13 reconsidered ${ }^{1}$
}

Ágnes T. Mihálykó,

University of Oslo

PGM P13 is one of the longest and most interesting pieces in Preizendanz's collection of Christian magical papyri at the end of PGM II. Inventoried as P.Cair. inv. 10236, it was first edited by A. Jacoby in 1900 together with a fragment of a gospel in Coptic (Jacoby 1900, 3155). The edition was accompanied by a detailed commentary, which focused on parallels from Christian apocrypha. Later, K. Preisendanz included it into PGM II with a few corrections to Jacoby's text (Preisendanz 1931, 200-202, with unaltered text in the second edition by A. Henrichs [1974, 220-222]). An English translation entered M. Meyer and R. Smith's collection Ancient Christian Magic: Coptic texts of ritual power(1994, No. 10, p. 35-36). Since then, the papyrus has only been discussed by A. Scibilia (2008) as an example of 'ritual contamination' due to the mention of Charon and the word $\alpha i \omega v .{ }^{2}$ This remarkable text however merits a new analysis, which could facilitate a more complex general understanding.

This article, besides a new translation, presents some corrections to Preisendanz's text on the basis of a black-and-white picture of the papyrus available on-line ${ }^{3}$. Although this cannot be considered a full re-edition due to the low quality of the image and the lack of autopsy, a few improvements to the text could be reached, as well as a more precise dating on the basis of palaeography. The text is followed by a detailed line-by-line commentary, which aims at situating the text in the context of the literature read and produced in the period in Egypt, as well as of the Christian ritual texts, and contains a few general observations on the magical and liturgical papyri as well. As a rule it presents additions and corrections to Jacoby's commentary and does not repeat what has been said there, unless it is important for the discussion. The article finishes with a detailed discussion of the salient features of this remarkable text, in particular the role of creedal formulas, the reference to the descent of 
Jesus, as well as the overall stylistic features of the text, and the curious mention of Charon, which allows us to catch a glimpse of the author, a Christian intellectual in search of ritual efficacy.

P.Cair. inv. 10263

$\mathrm{h} 18.7 \times \mathrm{w} 33 \mathrm{~cm}$

First half of $5^{\text {th }}$ century

Provenance unknown

TM 64558

The papyrus is a complete single sheet. All edges are preserved. It presents only a few lacunaealong the folds. On the upper edge, a margin of ca. $0.6 \mathrm{~cm}$ is visible, on the lower edge $c a .2 \mathrm{~cm}$. The hand is a fluent, practiced semi-cursive, with a few particular letter forms and ligatures. The forms of the letters, in particular $\alpha, \varepsilon, \eta, \kappa, \mu, v, v, \varphi$, and the presence of the ace of pick ligature (1. 8), together with the general impression of the writing speak for a date into the first half of the $5^{\text {th }}$ century; compare P.Köln III 151 (423 AD). The back is blank.

The image shows traces of six vertical and probably seven horizontal folds, although not all of them are entirely clear on the photograph. If the observation is correct, then the papyrus would measure approximately $\mathrm{h} 2.5 \times \mathrm{w} 4 \mathrm{~cm}$ in a folded state. The folds suggest that the object was used as an amulet. This is underpinned by the indication in P.CairoCat. p. 34 that it was "[a]pparently buried with a mummy". The apotropaic nature of the text further supports this affirmation. ${ }^{4}$

The language is full of irregularities, not so much of spelling as of syntax. As regards

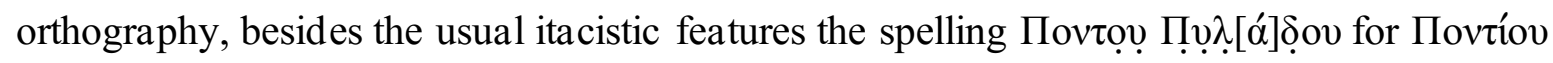
Пı $\lambda$ átov (1. 4) is worth noting. The syntax is frequently broken $(11.2,4-5,10,12,14)$, most notably in the tendency of the participles to slip into the nominative instead of the accusative. These traits suggest that the mother tongue of the author was Coptic. ${ }^{5}$ This is corroborated by semantics: the semantic field of the Coptic ıєıB allows the author to use the Greek ovv 
instead of $\kappa \varepsilon ́ v \tau \rho o v$ in paraphrasing Hosea 13:14 (see commentary to 1. 2). ${ }^{6}$ The elision is not effected in half of the cases. The scribe applies diairesis twice (1. 7).

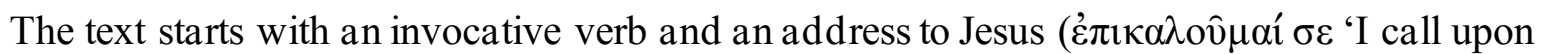
you'). The invocative mode is retained in the long string of participles in nominative enumerating various events of Jesus' life (1. 12). These focus on Jesus' victory over evil, and include a detailed description of Jesus' heavenly glory and descent into the und erworld. The prayer finishes with a request for protection from a number of 'possible evils' (11. 15-18) and an idiosyncratic doxology.

Even though this papyrus was included into the corpus of magical papyri by $\mathrm{K}$. Preisendanz, the text is best understood as a prayer recited as part of a rite, which was subsequently copied to serve as an amulet (as it was suggested already by the first editor Jacoby 1900, 36 and later by Maltomini 1982, 151 n. 4). The wording of the text, phrased as a continuous invocation with a request with no reference to use as amulet, supports this hypothesis. Moreover, PGM P13 finds a fairly close parallel in the "exorcism of the oil of the sick' from the miscellaneous Barcelona codex (P.Monts.Roca 156 a.6-b.3). The latter text belongs to a rite together with the prayer of the laying on of the hands on the sick (P.Monts.Roca 155 b.19-156 a.5) which precedes it in the codex (Roca-Puig 1994 99-111). The Barcelona exorcism and PGM P13 share a parallel structure and similarities in

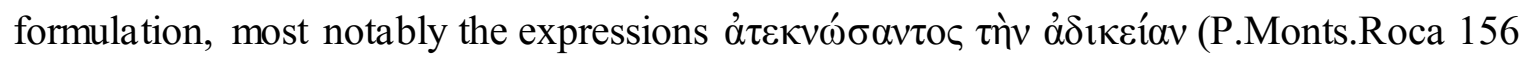

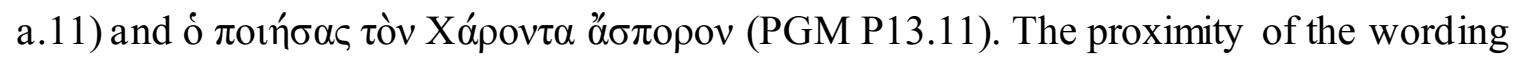
suggests that they were used in similar ritual context, and that the exorcism, or a similar ritual text, could have served as a model for the composer of PGM P13. However, the rite PGM P13 was intended for was probably less of an exorcism in the narrow sense (i.e. a prayer to drive away already present evil forces) than a more general apotropaic prayer, as the 'loosely attached' supplication (Jacoby 1900, 47) asks for protection against a number of evil forces, 
which have demonic nature as well. The two types of prayer are closely connected. This case of an apotropaic prayer uttered in the framework of a protective-exorcistic rite, and then reused as an amulet exemplifies the difficulties one is faced with when trying to distinguish 'magical' and 'liturgical' texts.

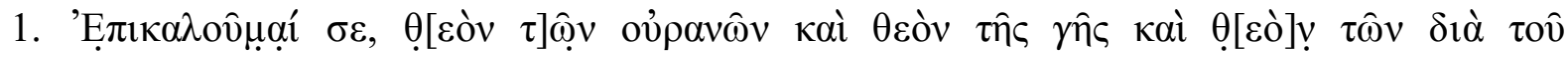

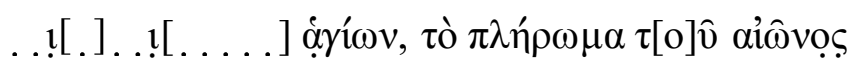

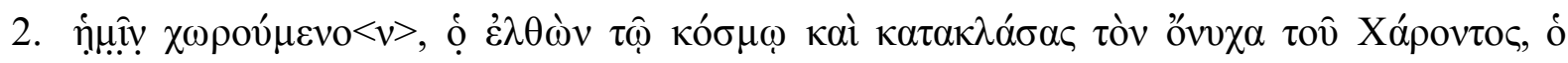

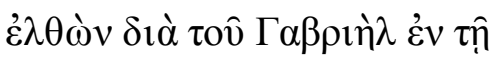

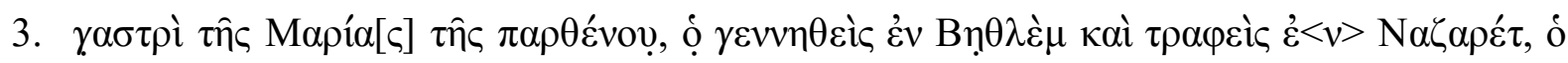

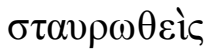

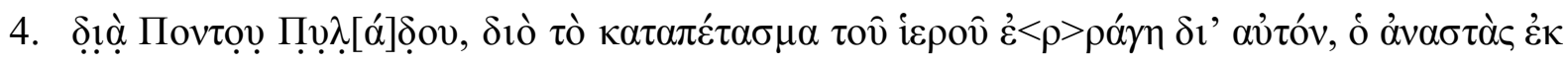

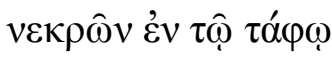

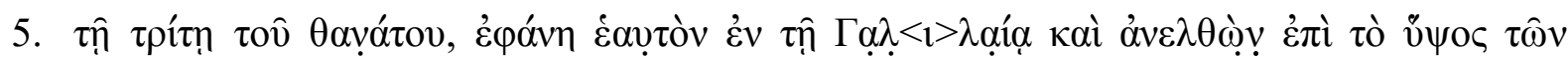

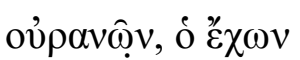

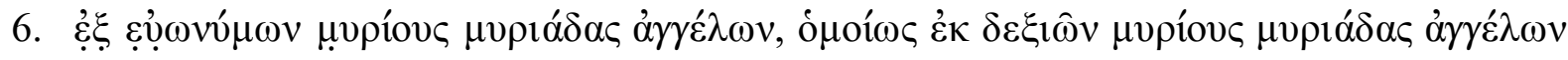
$\beta о \omega ิ \nu \tau \varepsilon \varsigma$

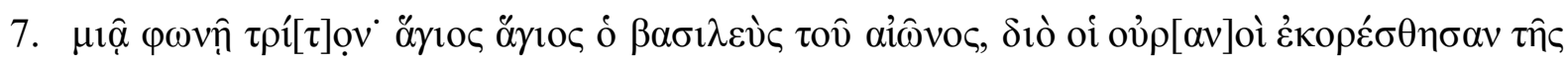

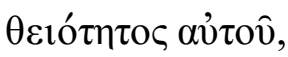

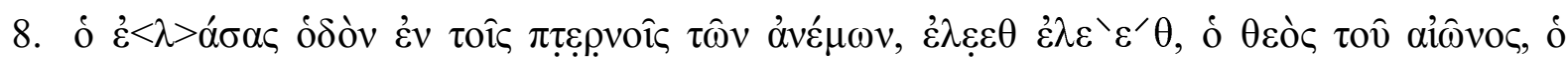

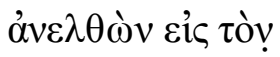

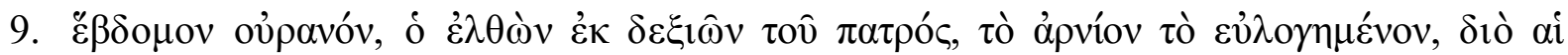
$\psi v \chi \alpha \grave{~} \varepsilon \lambda \varepsilon v \theta \varepsilon-$ 


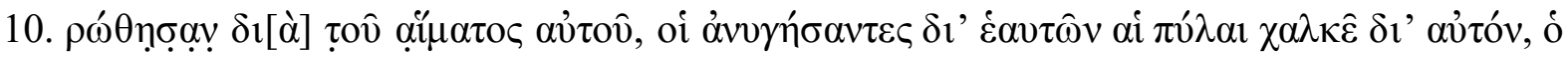
$\kappa \alpha \tau \alpha \kappa \lambda \alpha ́ \sigma \alpha \varsigma$

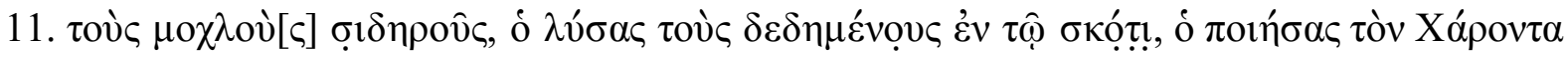
"’ $\sigma \pi \mathrm{o \rho ov,}$

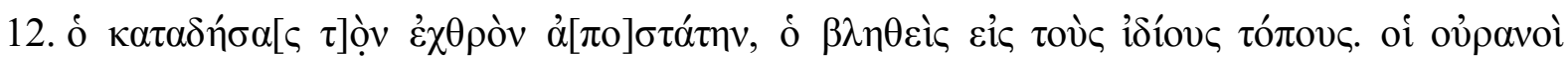

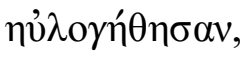

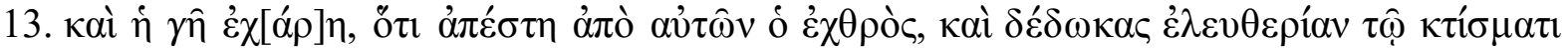

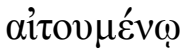

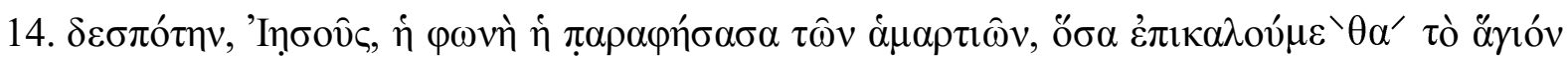
бov o้vo $\mu \alpha$.

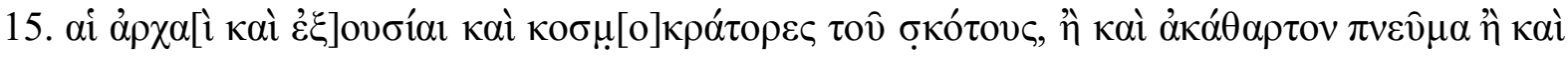
$\pi \tau \hat{\omega} \sigma \iota \varsigma, \delta \alpha i ́ \mu o v \varepsilon ̣ \varsigma$

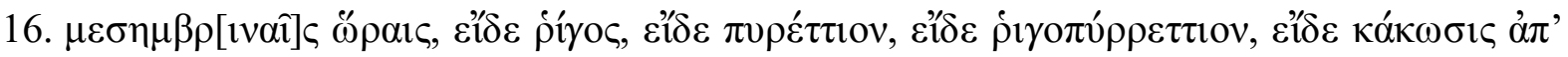
$\stackrel{\alpha}{\alpha} \theta \rho \omega \dot{\pi}(\omega v)$,

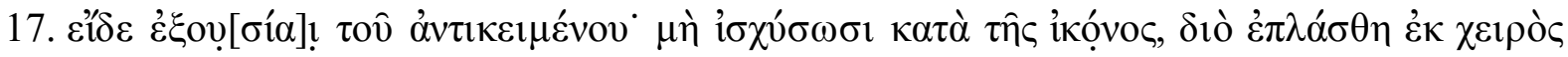
$\tau \hat{\eta} \varsigma \sigma \hat{\eta} \varsigma$

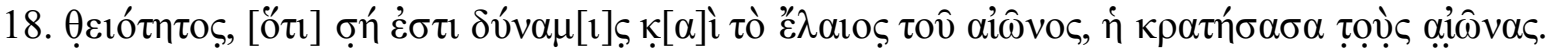

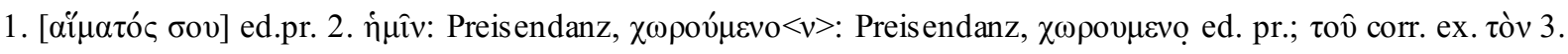

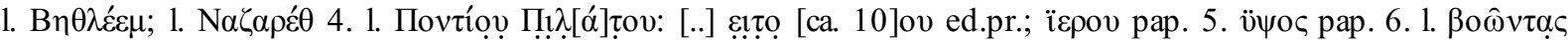

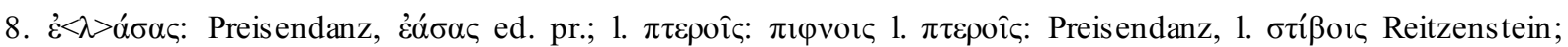

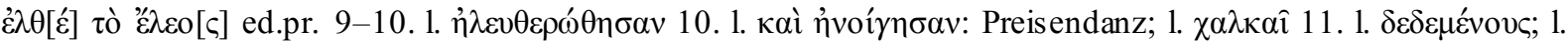

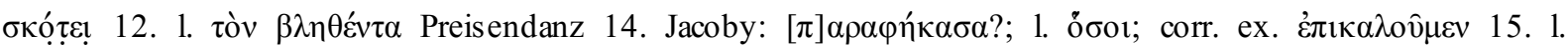

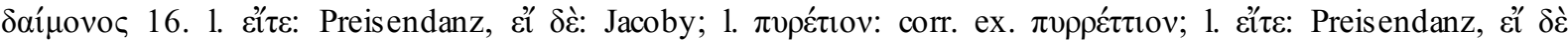

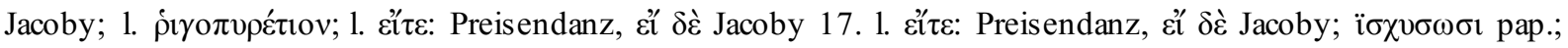

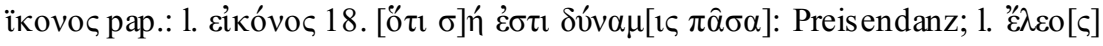


'I call upon you, God of heavens and God of earth and God of the saints through the holy blood (?), the fullness of the aion, who was sent for us (?), who came to the world and broke the claw of Charon, who came through [the agency of] Gabriel in the womb of Mary, the virgin, who was born in Bethlehem and raised in Nazareth, who was crucified by Pontius Pilate, therefore the veil of the Temple was torn because of him, who rose from the dead in the grave on the third day following his death, who showed himself in Galilee and ascended to the top of the heavens, who has on his left ten thousand times ten thousand angels, likewise on his right ten thousand times ten thousand angels crying with a single voice thrice: 'Holy, holy is the king of eternity', wherefore the heavens are full of his divinity, he who drives his way on the wings of the winds. Eleeth, Eleeth, the God of the aion, who ascended to the seventh heaven and came from the right hand of the father, the blessed lamb, wherefore the souls were set free through his blood, and to whom the gates of brass opened by themselves, who broke in pieces the bars of iron, who released those who were bound in darkness, who made Charon without offspring, and bound the apostate enemy, who was thrown into his own places. The heavens blessed him, and the earth rejoiced, because the enemy turned away from them, and you granted freedom to the creature who petitions the master, Jesus, the voice that discharged us all from sin, those who invoke your holy name. The principalities and powers and cosmic rulers of darkness, or an unclean spirit, or fall of a demon at noontide, or chill, or fever, or ague, or harm from people or from powers of the adversary, shall not prevail against the image, as it was created by the hand of your divinity, for yours is the power and the mercy of the aion, which rules eternity.'

\section{Commentary:}

1. 'E $\pi \iota \kappa \alpha \lambda$ ov̂ $\mu$ ấ $\sigma \varepsilon:$ the verb, though present in the Bible (Rom. 10:12 and Ps. 144:18 in participle form; 4 Macc. 12:17), and in patristic texts, is rather rare in the Egyptian liturgical 
language in comparison with the standard $\pi \alpha \rho \alpha \kappa \alpha \lambda$ ov $\mu \varepsilon v$ (see Pap.Colon. XXVIII, p. 224 and 228). In a finite form, in initial position and followed by an invocation and glorification of God, it is attested in P.DeirBala'izah fol. I v 11 (Roberts and Capelle, 1949 18); P.Berol. inv. 13415.12 (Schmidt 1914, 68), and in an exorcism of the oil of the sick (prayer 17) from the euchologium of Sarapion of Thmuis (Johnson 1995, 66). On the other hand it is rather frequent in magical prayers (see PGM III p. 95-96 ${ }^{7}$ ). The reluctance of Egyptian liturgical texts to use this verb and the preference for the synonym $\pi \alpha \rho \alpha \kappa \alpha \lambda \hat{\omega}$ may be a deliberate demarcation from the magical usage.

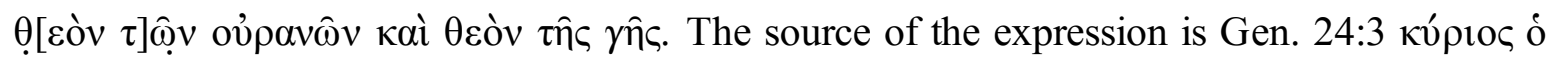

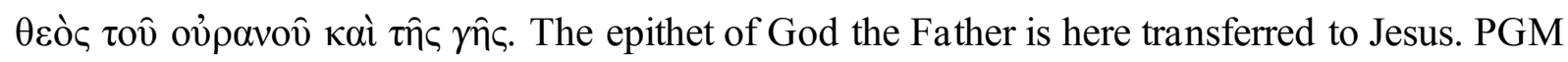
$\mathrm{P} 13$ is one of the few prayers on papyrus which are directed to the Son instead of the Father. Others include O.CrumST17 and 18, P.Rain.UnterrichtKopt. $197 \mathrm{v}\left(6-7^{\text {th }}\right.$ cent. $)=$ BM EA 14180 (O.Brit.Mus.Copt. I p. 24. pl. 18.3, 6- $7^{\text {th }}$ cent.), P.Mon.Epiph. 45 (6-7 $7^{\text {th }}$ cent.), P.Oxy. LXXV $5024\left(6-7^{\text {th }}\right.$ cent.) and possibly P.Bal. I 30 fol. 8 b $67-69$ ( $7^{\text {th }}$ cent.). Of these, O.CrumST 18 as well as P.Mon.Epiph. 45 are of private character, the other four belong to the community worship. To these can be added the anaphora of Saint Gregory, one of the three anaphoras of the Coptic church, attested since the late $6^{\text {th }}$ century (Henner 2000, 35-82). Predilection for addressing the Father in community prayers is in line with Origen's insistent, albeit isolated, admonition to pray exclusively to the Father (or. 15). Amulets address Christ (PGM P5b ( $5^{\text {th }}$ cent.), 6c ( $6^{\text {th }}$ cent. $), 18$ (5/6 ${ }^{\text {th }}$ cent.), Suppl. Mag. I $30\left(5 / 6^{\text {th }}\right.$ cent. $)$, I $31\left(5 / 6^{\text {th }}\right.$ cent.), SB XVIII 13602 ( $7^{\text {th }}$ cent.)) more often than the Father (PGM P9 (6 ${ }^{\text {th }}$ cent.) and P21 $\left(3 / 4^{\text {th }}\right.$ cent. $\left.)\right)$. On the theological questions concerning the address to the Father or the Son see Jungmann 1962 and a more recent revision of his thesis by Gerhards 1984, 176-210.

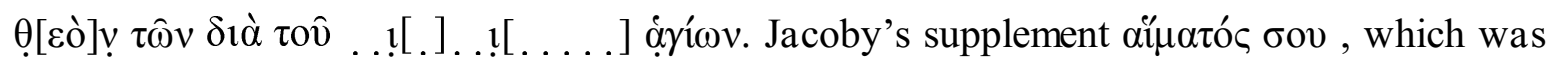
based on the parallel in 1. 9-10, cannot be reconciled to the traces of ink that are visible on the 
fragment at the top, which is dislocated on the image and should be attached immediately to the edge on the right side of the lacuna. The traces on the other hand may support the

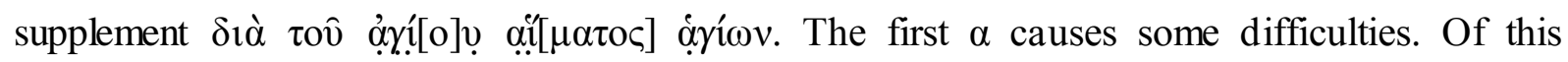
letter, only a vertical at the top and a very small oblique to the right of the $v$ of $\tau$ ov can be seen, but it is not impossible, if we compare the $\alpha$ of $\delta 1 \grave{\alpha}$ in 1.4 . The supplement is at best plausible. The construction would be smoother with a $\sigma o v$, which could be supplied after aifatoc, although the space does not seem to be sufficient. The dislocated state of the fragment makes the number of missing letters hard to determine.

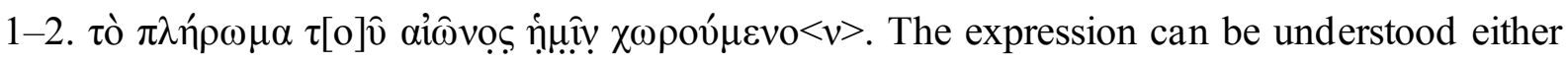
as a vocative (or as a nominative functioning as vocative) or as a temporal accusative. Its

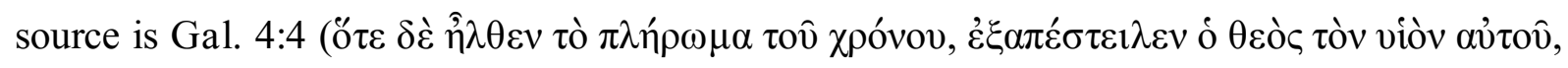

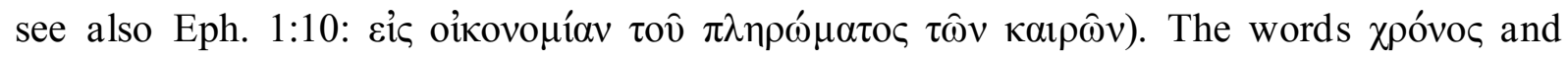

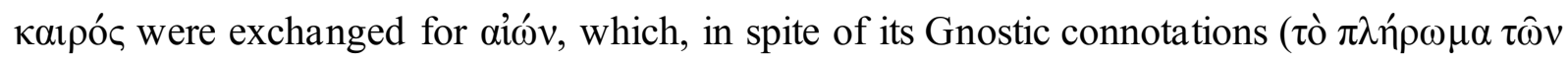
aív $\omega v$ in Gnostic context means the assembly of the aions [Lampe 1961, 1059]), can be interpreted in the framework of mainstream Christianity; it means 'time', 'age' or 'the eternal world' as opposed to the present time (Lampe 1961, 55-56, Jacoby 1900, 40 was of similar opinion). In two creedal statements from $4^{\text {th }}$-century Egypt, which were preserved in literary sources, that of the patriarch Alexander (Thdt. h. e. 1, 4, 46; 53; 54, cf. Kelly [1960] 1979, 188-189) and that of Macarius (PG XXXIV 212-213, cf. Kelly [1960] 1979, 190-191 and

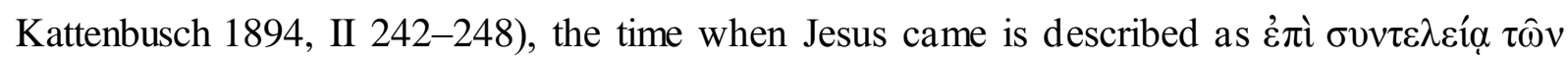
aív $\omega v$. Even if the meaning 'time' or 'age' is preferable to the Gnostic 'aion', it is less likely

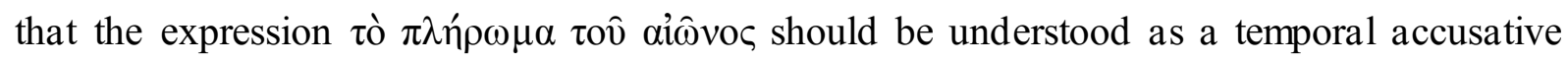
here. As from here on the accusative governed by $\dot{\varepsilon} \pi \iota \alpha \lambda$ ov̂ $\mu \alpha$ slides into a series of nominatives (perhaps understood as vocatives), the vocative of the neuter, which is identical 
to the accusative, could facilitate confusion. This is, however, not compelling; the author of the text changes from accusative to nominative also in 1.12 for no apparent reason.

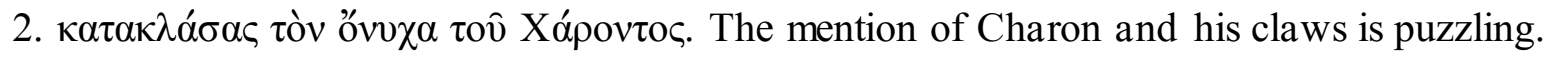
This is the element which attracted Jacoby's attention and led to the publication of the papyrus. Drawing on a thesis of Wilamowitz, Jacoby thought that an ancient belief that imagined Charon with claws is embodied in this text, and in its assumed parallel, the gospel edited in the first half of his publication (Jacoby 1900, 19, 31, 37). However, the image of Charon with claws in Greek popular imagination does not find support in the contemporary sources (see survey below), and this strange expression can be explained in another way. The phrase finds a very close parallel in a fraction prayer in the Great Euchologium of the White Monastery fol. 181 r3-4 пеNтдч2шрв мпеiєiв мпмоY (Lanne 1958, 368-69). Though the manuscript is datable to the turn of the $10-11^{\text {th }}$ centuries (Suciu 2011), the text may be

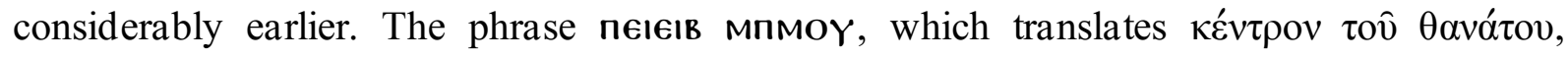

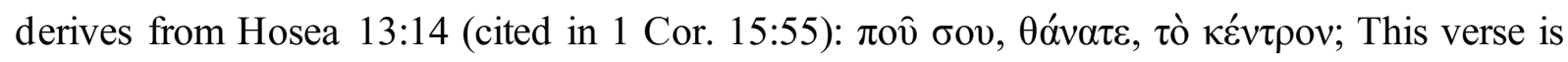
frequently cited by early Christian authors discussing the descent of Christ to the underworld

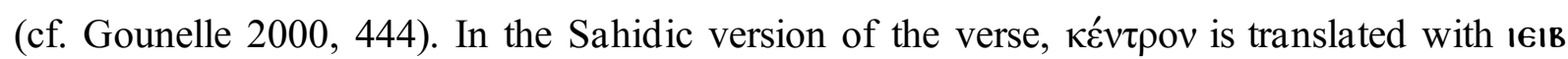
(Thompson 1932, 145, and also in the Achmimic version of Hosea, see Crum, Dict. 76). This expression is used also in the fragmentary gospel edited in Jacoby 1900 (p. 6 1. 18). However, IEIB can also signify 'claw' or 'hoof', translated by the Greek o'vv (Crum, Dict. 76). This semantic overlap in Coptic can account for the Greek expression. Thus, the expression

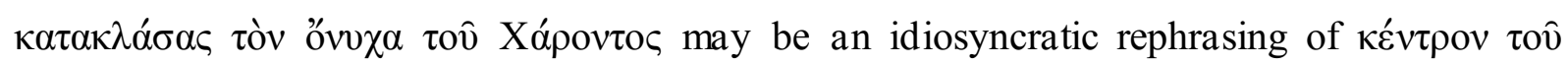
$\theta \alpha v \alpha ́ \tau o v$, based on a semantic extension in Greek stimulated by the Coptic, the probable mother tongue of the author, which squares well with the numerous other rephrasings of Biblical verses in the text. 
This in turn means that the name of Charon, the ferryman of the classical Greek underworld here stands for 'death'. This choice is striking. The equation of Charon with death itself in this text was already affirmed by Jacoby $(1900,37)$, and it is known also from other sources, mainly from outside Egypt (Waser 1898, 88-90). Charon had started to be disconnected from his occupation as ferryman and to become assimilated to death itself already by the $1^{\text {st }}$ century AD. Probably the first witnesses to this process are two epigrams in the Anthologia Palatina, AP VII 671 (attributed to Bianor), and possibly AP XI 133 (attributed to Lucillius, possibly a contemporary of Nero). Later, the equation of Charon with death is attested in Lucian (Demon. 45, though the satirist dedicates an entire dialogue, Charon sive contemplantes, also to the traditional image of Charon as ferryman), and in two more epigrams of the anthology, AP VII 603 (attributed to Julian the Egyptian, $6^{\text {th }}$ century) and XVI 385 (an adespoton of the Byzantine period). A similar picture of Charon emerges from a tale in the late antique Pseudo-Dosithean schoolbook (iatpò $\alpha^{\prime \prime} \tau \varepsilon \chi v o c$, Fab.Dos. 7 [ Hausrath Vol. I.2 124]). More witnesses to this equation come from inscriptions: I.Thess. I 108 (Thessaly, late $2^{\text {nd }}$ cent. AD), I.Chios 281 (Chios, date unknown), IGUR II 836 (Rome, date unknown), IGUR III 1149 (Rome, $4^{\text {th }}$ century AD). In these sources, no reference is made to the occupation of Charon as the ferryman, and he is usually pictured as snatching

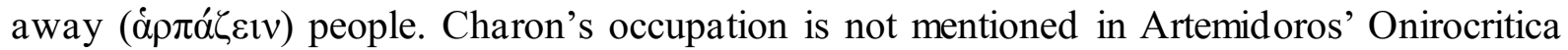
(I 4) either, where his appearance in a dream playing dices with a person forewarns peril of

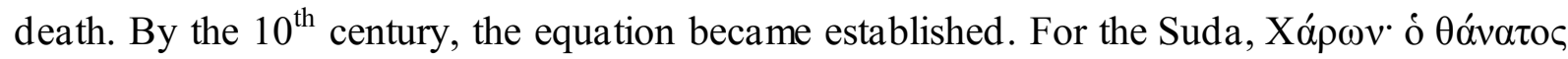
(Suid. X 135). The career of Charon as the terrible demon of death continued in the Byzantine popular imagination; in the $15^{\text {th }}$ century he re-emerges in epic and acrostic poetry as a death demon with bows and arrows and even takes the role of a hunter (Waser 1898, 91-103).

This equation, however, is not widely attested in Egypt. Apart from our text, we have only one source for it, the aforementioned epigram by Julian the Egyptian, and in this case, even if 
the attribution of the Anthologia is correct, the Egyptian context is not necessary, as Julian belonged to the learned Constantinopolite circle of the poet Agathias and held important court offices, including that of the praetorian prefect (Neue Pauly VI 16). In his two other epigrams mentioning Charon, AP VII 585 and 600, Julian refers to him as the ferryman. An unedited Greek funeral inscription addressed to Isis and Osiris from a private collection in Germany ${ }^{8}$ contains the name Charon with the adjective ó $\pi \imath \sigma \tau$ os. In this text, Charon is a being to whom

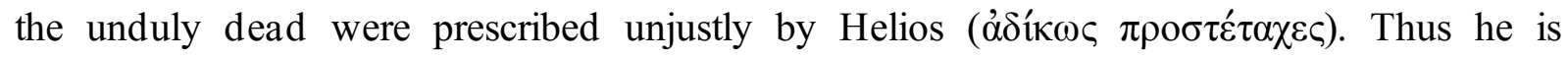
essentially a substitute for death. The last source from Egypt mentioning Charon is a collection of spells, PGM IV (copied in the $4^{\text {th }}$ century). In 1.1452 Charon features in an erotic charm among a series of chthonic powers of the Greek and, to a lesser degree, of the Egyptian underworld. They include Ariste, eponym for Artemis, Persephassa, a variant name for Persephone, Erebos and the judge of the underworld Aiakos (cf. Betz 1986, 65-66). This charm gives the impression of a learned endeavour to provide an exhaustive list of the chthonic powers of the Greek classical underworld, and juxtapose it to a few from the more familiar Egyptian ones. The funerary inscription and PGM IV are the only attestation of the name that are associated with a traditional Egyptian context. Charon does not seem to have had a place in the traditional Egyptian underworld imagination, which had a ferryman of its own, attested in the Book of the Dead (spell 99) as well as in funeral iconography, even as late as the later Ptolemaic-early Roman period (Stadler 2012, 283-84). This creature 'survived' in Coptic imagination as the figure of John the Baptist, who ferries the souls over the rivers of fire in a golden boat in the Encomium of John the Baptist (Wallis Budge, 1913 140/347). However, despite the tendency in Egypt to equate local gods with lesser-known figures of classical Greek mythology, such as Seth with Typhon or Petbe with Nemesis (Frankfurter 1998, 112 and 117), there is no indication that the name Charon was equated with the ferryman of the traditional Egyptian underworld. The low prominence of Charon in 


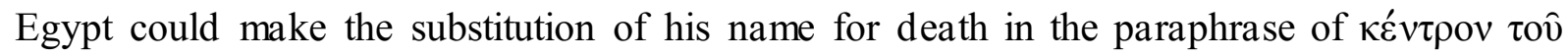
$\theta \alpha$ ó́

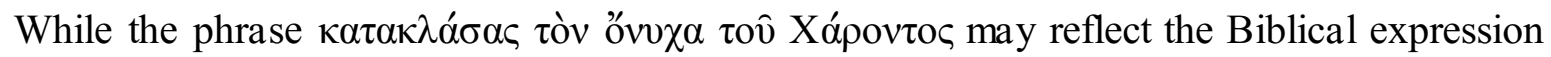

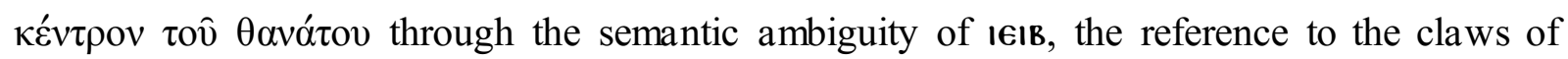
death can reasonably be expected to rely on contemporary imagination of death. Traditional Egyptian underworld imagination included many demons, which constituted a peril to the soul. These frequently had animal heads, or could be animals themselves, but they usually had knives in their hands instead of claws. Demons in the form of carnivorous mammals (wolves, dogs, jackasses, lions) and birds are underrepresented compared to crocodiles and snakes, and even if they are present, the reference is to their head (Zandee 1960, 147-160, 192-197, 206208). The Coptic apocrypha describe the demons in similar terms, although they frequently draw on a Biblical or apocryphal tradition (cf. Frankfurter 2013). Whatever the sources of these descriptions are, however, the claws of death did not seem to have made considerable impression on them. Only one, the Homily on Abbaton by Timothy the Archbishop (known from London, BL Or. 7052, a manuscript copied in 982, but the text is probably considerably earlier) refers to claws. He mentions the long claws 'like reaping-knives' of Abbaton, the angel of death (Wallis Budge 1914, 241/489). Abbaton is represented with similar features by a $10^{\text {th }}$ century fresco from a church in Tebtynis, though here only the toes of the figure are claw-like, while another death demon has claws on its hands (Walters 1989, 201, 203). The image of death with claws was apparently not common in Egypt, and although the expression could still bear witness to a less widespread portrayal, the role of the semantic field of the Coptic IEIB in achieving this idiosyncratic modification of the Bible verse has to be considered more decisive.

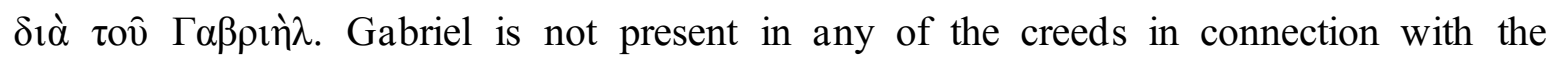
incarnation; it is the Holy Spirit who recurs (Kelly [1960] 1979, 103, 289, 293 and 297). The 
unusual focus on his role has Gnostic connections. In the Pistis Sophia (ed. Schmidt 1905, p. 7 1. 27 and 30; p. 8 1. 32), Jesus descends through the aions and speaks with Mary in the likeness ( $\tau \dot{\pi} \pi \circ \varsigma$ ) of Gabriel. This image is taken up by the mid-2 $2^{\text {nd }}$-century Epistle of the Apostles (see discussion in Barbel [1941] 1964, 236-240) and a short hymn in MPER N.S. XVII $34.9-10\left(7-8^{\text {th }}\right.$ cent.). However, it is missing from the works of the 'mainstream Christianity', which induced Barbel to consider it of Gnostic character even in the antiGnostic Epistle of the Apostles. On the relationship between Gabriel and Jesus in general, see Barbel (1941) 1964 235-262. Our author does not go beyond mainstream interpretations of Luke's annunciation scene in his reference to Gabriel (Barbel [1941] 1964 253). His reference to the Gnostic tradition remained between the lines, and could serve to allude to esoteric knowledge.

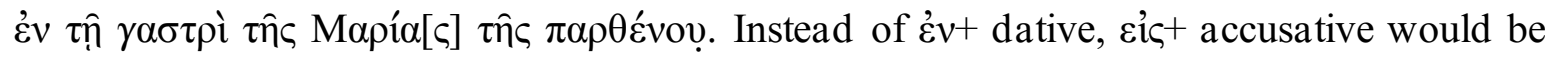
expected. Reference to Mary is frequent in creeds, but her womb is never mentioned. The

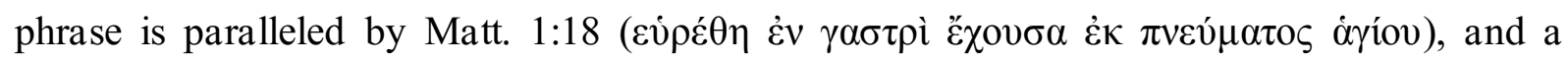

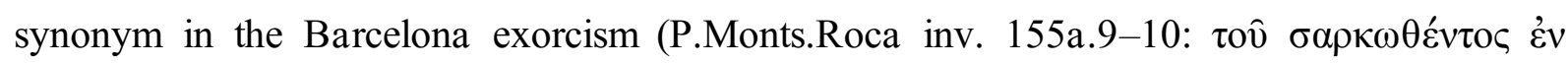
$\pi \alpha \rho \theta \varepsilon \dot{v} \varphi \mu \eta^{\prime} \tau \rho \alpha$ ). Both the Bible and the exorcism (or a similar one) could have served as a source and prompted the mistaken $\dot{\varepsilon} v+$ dative.

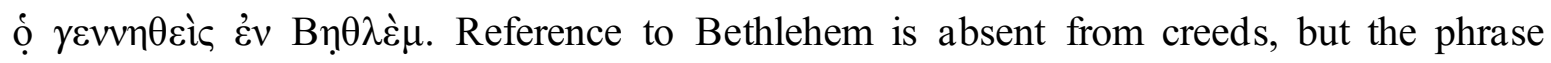
echoes Matt. 2:1.

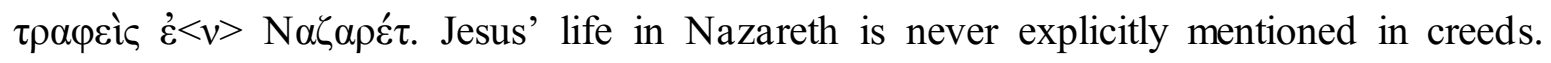
Bethlehem, Nazareth and Galilee figure together in a Christmas hymn P.Vindob. G 2326 (5-

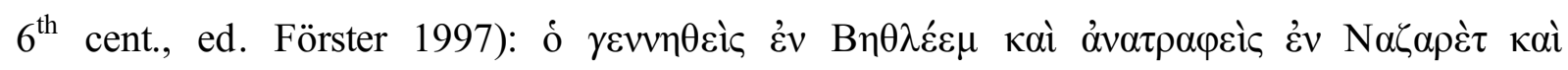

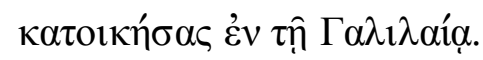

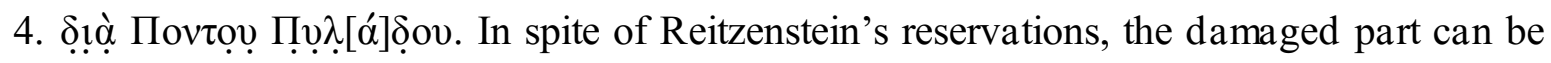
read as a reference to Pilate, even if it involves a number of mistakes. An accented 1 could be 
lost before a back vowel, although this phenomenon is more frequent after a nasal (Gignac 1976, 302-303). The v-1 interchange occurs both in unaccented syllables and in transcribed Latin names (Gignac 1976, 269). The $\delta-\tau$ interchange is common in the papyri (Gignac 1976, 82-83). The name of Pilate apparently caused problems to the scribe. The traces at the beginning of the line are unclear on the photograph, yet they seem to fit Sọ̣d better than the customary $\dot{\varepsilon} \pi$ ì. Pilate occurs often in creeds, including the Nicene-Constantinopolitan, in connection with Jesus' death.

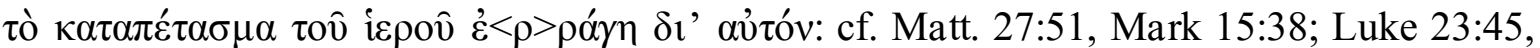
where however the verb $\dot{\varepsilon} \sigma \chi i \sigma \theta \eta$ and the noun vaov is employed. The Matthew and Mark

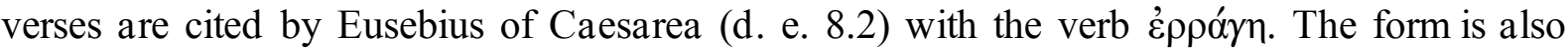

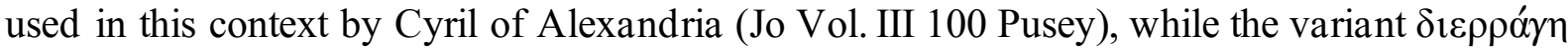
is employed by the Gospel of Peter (20.1). The verb $\rho \eta \eta \gamma v u \mu$ and its derivatives are moreover present in the language of the papyri.

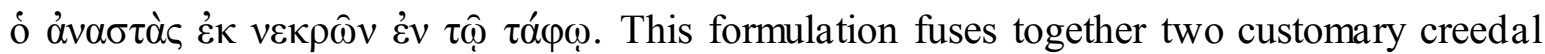

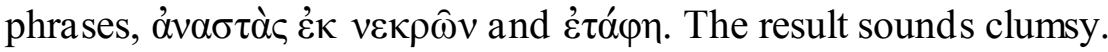

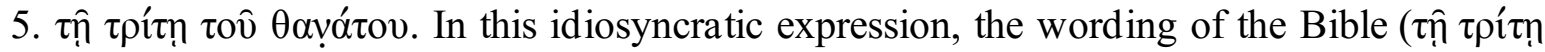

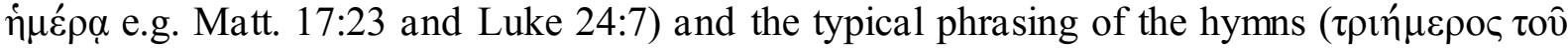

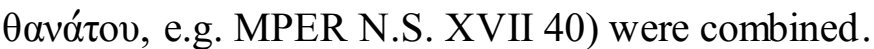

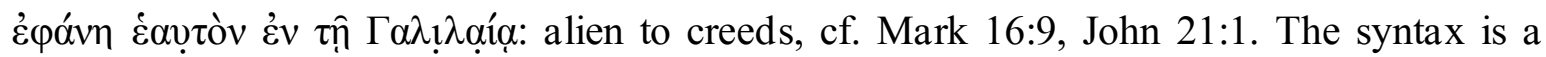

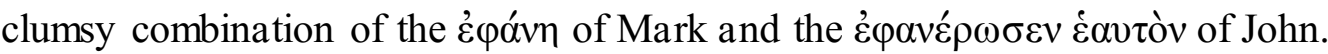

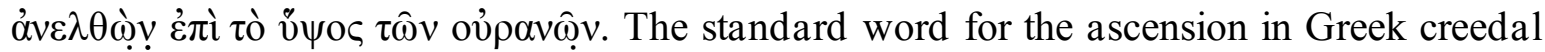

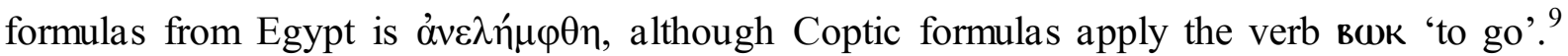

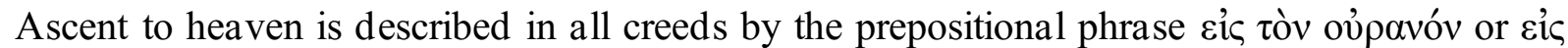

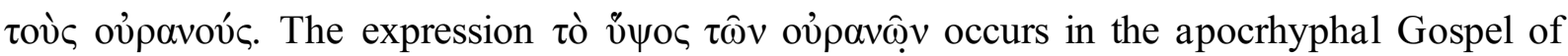




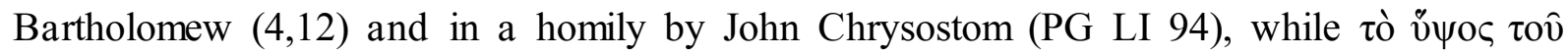
oủpavô̂ occurs in Ps. 102:11 and Isa. 38:14.

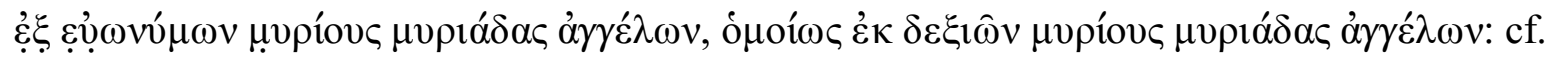

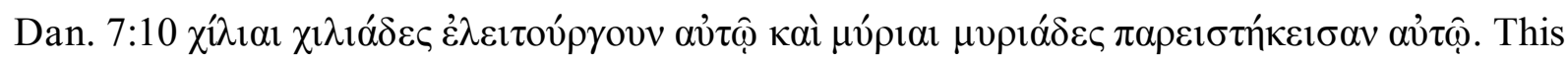
verse is cited in the description of heavenly worship in the pre-Sanctus part of several Egyptian anaphoras (e.g. the anaphora of St Mark: Cuming 1990, 37, the anaphora of Barcelona: Zheltov 2008, 484 [cf. 474 and 488. n. 70], the euchologium of Sarapion: Johnson 1995 46). In PGM P13 it is analogously followed by a rephrasing of the Sanctus or biblical Trisagion. The angelic host in the pre-Sanctus appears in combination with the Sanctus also in four Coptic magical texts (Meyer and Smith 1994, No. 71, 89, 91, 121).

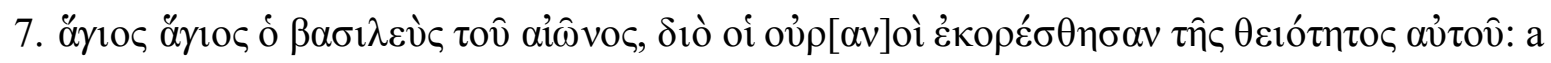

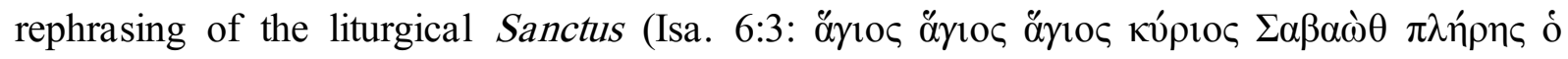

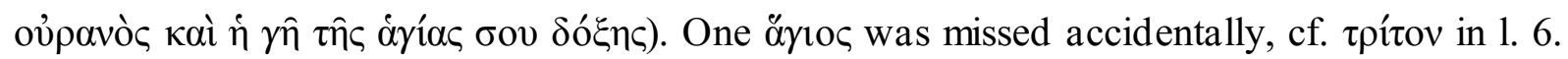

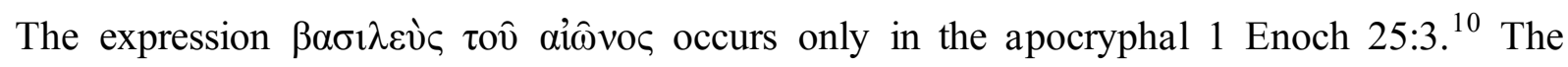

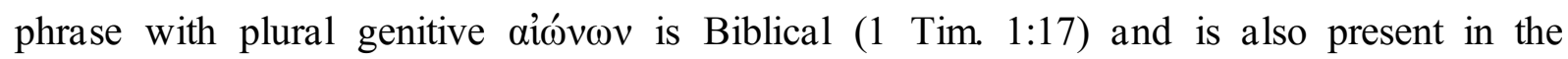

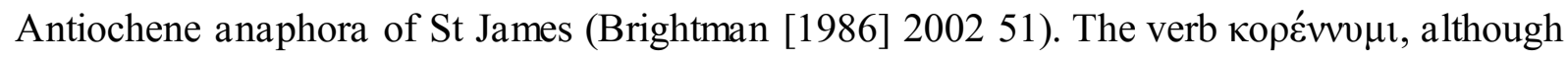
more frequent in classical Greek, is also used in the late antique monastic literature (e.g. V.Pach. $\Sigma 54$ ). Its primary meaning is 'to saturate', therefore it sounds odd in this context, even though it can also signify simply 'to fill' (Acts 27:38, 1 Cor 4:8).

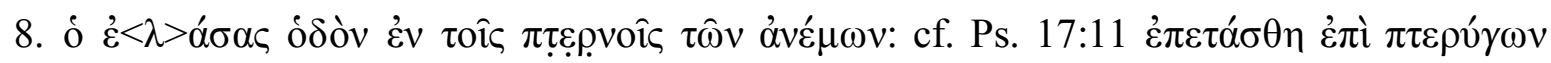

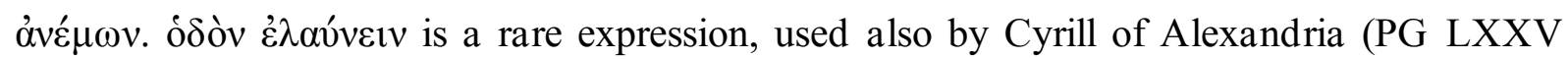
376) and Didymus Caecus (Ps 34.4). $\pi \tau \varepsilon \rho o ́ v$ is a more classical variant of $\pi \tau \varepsilon$ \&v $\xi$, which is the common form in the Bible and the liturgy.

$\dot{\varepsilon} \lambda \varepsilon \varepsilon \theta \varepsilon^{\prime} \lambda \varepsilon^{`} \varepsilon^{\prime} \theta$. The reading printed by Jacoby and Preisendanz, $\dot{\varepsilon} \lambda \theta[\dot{\varepsilon}] \tau$ iò ${ }^{\prime} \lambda \varepsilon \circ[\varsigma]$, which was considered doubtful by Grenfell on a collation with the original (Jacoby 1900, 33 n. 7), 
does not agree with the traces visible on the photo. A more compatible reading is $\dot{\varepsilon} \lambda \varepsilon \varepsilon \theta$ $\dot{\varepsilon} \lambda \varepsilon^{\prime} \varepsilon^{\prime} \theta{ }^{11}$ The name 'E $\mathrm{\lambda} \varepsilon \eta \theta$ (the $\eta-\varepsilon$ exchange is common in papyri [Gignac 1976, 242-247]) appears in a variant text of the Testament of Solomon (VI 7 MacCown, the section is contained only in Paris, BnF Ancients fonds grecs 38 (16 ${ }^{\text {th }}$ century)). According to this section 'The Romans' could exorcise Beelzebub by 'the name of the power (of) Eleeth', while 'the Hebrews' were supposed to use the numeral 644, and 'the Greeks' the name Emmanuel. In PGM P13, as in the Testament, Eleeth is a powerful name of Jesus. The fact that the scribe missed and subsequently added an $\varepsilon$ in the second $\dot{\varepsilon} \lambda \varepsilon \varepsilon \theta$, and that he left a space before, between and probably after the two words in a text otherwise written in scriptio continua may also indicate that he was not familiar with the word, and understood it as a divine name.

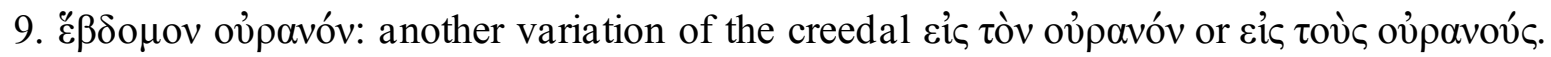
The number of heavens was an important matter of speculation in late antiquity (cf. Wright 2000). In Jewish and early Christian apocryphal works it could vary, including solutions with three, five or ten (Bauckham 1998, 364, Wright 2000, 153 and 163), but number seven was the most widespread (Bauckham 1998, 57). The Coptic literature shares this general opinion. The idea gained popularity in the magical texts from Egypt and elsewhere. The seven heavens were connected frequently with the seven archangels (Kotansky 1995, 149-150). However, these ideas did not meet the approval of the Church authorities. Clement of Alexandria (Strom. VI 16) mentions the teaching of the seven heavens among the falsities of the Gnostics. Origen (Cels. VI 21, 1-5) deprives it of Scriptural founding. The author of PGM P13 bases his variation on a Jewish-Christian tradition, which was apparently widespread among the Christians, also in Egypt, even if it did not meet the approval of the Church authorities.

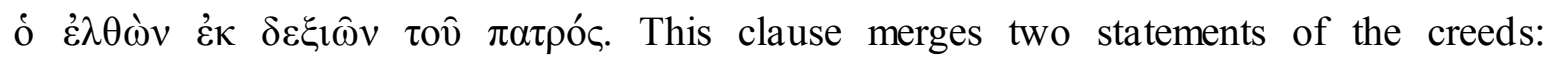

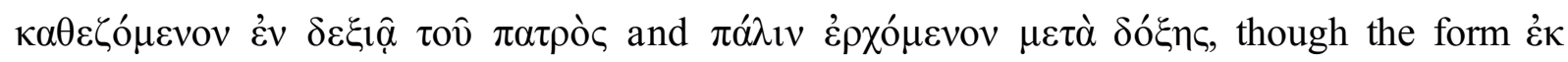


$\delta \varepsilon \xi 1 \hat{\omega} \nu$ is present also in the anamnesis of the anaphora of St Mark (Cuming 1990, 44). The erroneous aorist could be prompted by the aorists in the previous and subsequent clauses and the narrative flavour of the passage.

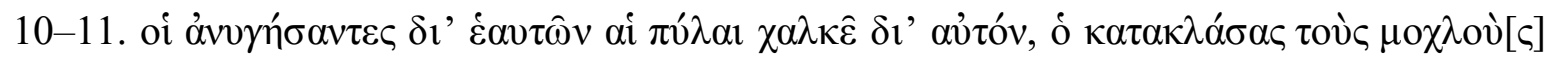

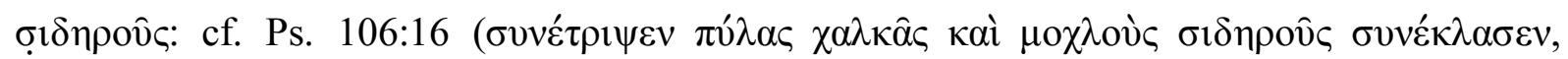
similar Isa. 45:2). The gates of brass and the bars of iron were traditionally connected to the descent to Hades in patristic exegesis (Bauckham 1998, 42). They are also present in the Coptic representation of the descent, in the Gospel of the Resurrection of Jesus Christ by Bartholomew (Wallis Budge 1913, 6 and 184, although the text is fragmentary, the reference to the psalm is clear), and in the Discourse on Abbaton by Timothy the Archbishop (Wallis Budge 1914, 240 and 488). They also played an important role in the descent narrative of the Gospel of Nicodemus (Gounelle 2006, 320). The verse was altered. The first half was merged

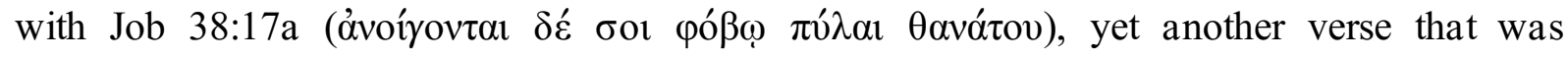
frequently used in connection with the descent (Bauckham 1998, 42). The fusion ended up in

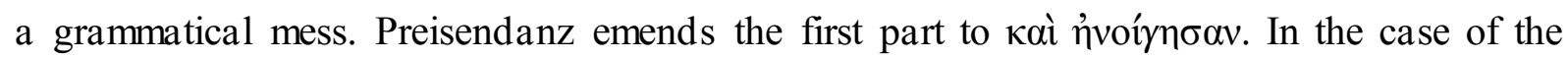

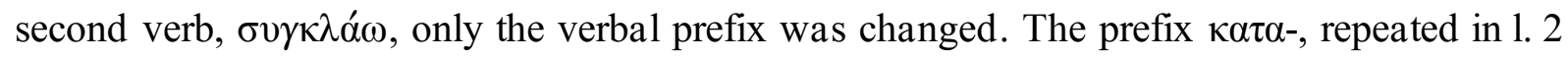
and 12, emphasizes the totality of Jesus' victory (Maravela 2014, 316). The change of the prefix served to underpin this rhetorical aim.

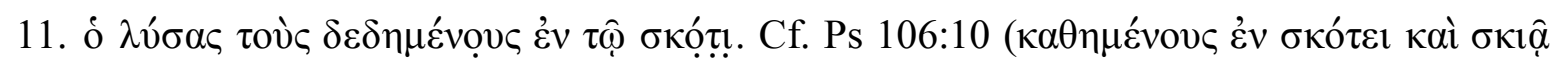

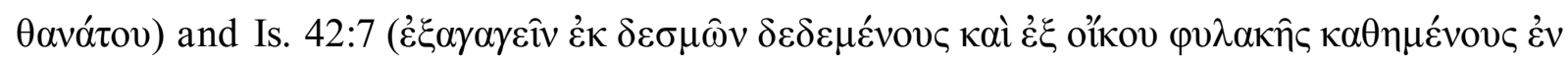
$\sigma \kappa o ́ \tau \varepsilon 1)$. Both verses were used with reference to the descent, e.g. by Cyril of Alexandria (PG LXXII 537), Isaiah already by the $2^{\text {nd }}$-century collection of Christian hymns known as the Odes of Solomon (42:16b).

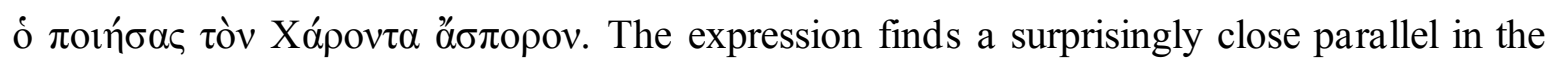

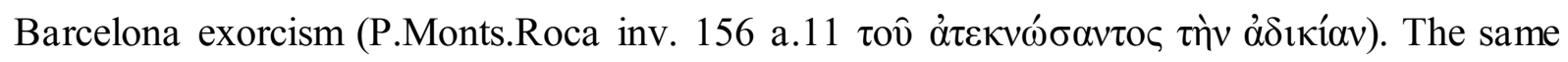




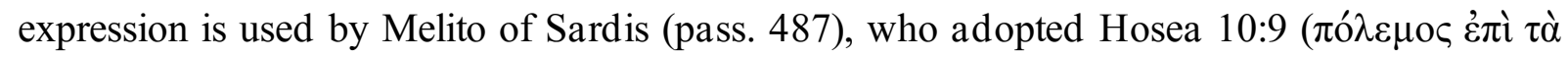

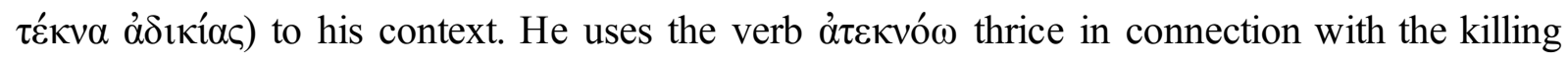
of the Egyptian firstborns (pass. 112, 203, 231), and in 1.487 he links the expression $\tau$ ov

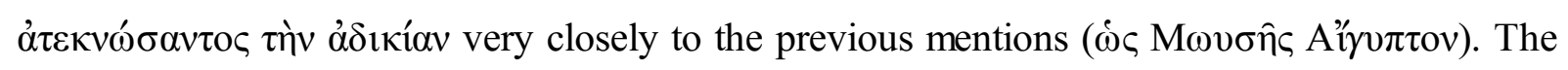

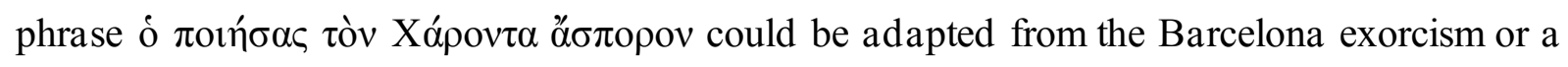
similar text, and ultimately from Melito. This supports the interpretation 'who made Charon without offspring', already proposed by Jacoby 1900, 43. The variation, however, created an idiosyncratic wording, involving again Charon. The adjective $\alpha$ $\sigma \pi \circ \rho \circ \varsigma$ was applied usually to Mary or Jesus by the Church fathers and hymnists, in connection with Jesus' miraculous incarnation (Lampe 1961, 246b). Clement of Alexandria (q.d.s. 36:6) uses it for an evil person, paired with ớ ${ }^{\prime}$ ovoc. The $5^{\text {th }}$ century Egyptian poet, Nonnos of Panopolis employs the adjective twenty times in his two poems, among them also in the meaning 'childless' (D. 2.221). The adjective is also very frequent in papyri, in connection with unsown land.

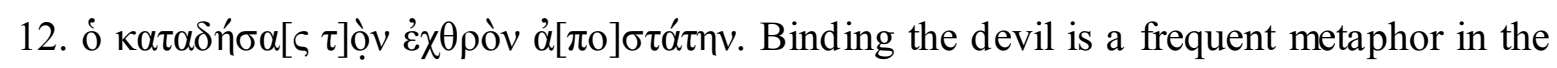
descriptions of the descent (MacCullogh 1930, 231-33). Its original source is an exegesis of Matt. 12:29. The verse is cited by Melito and the Barcelona exorcism(P.Monts.Roca inv. 156 a.11-12) in this meaning. $\dot{\varepsilon} \chi \theta \rho o ́ \varsigma$ and $\dot{\alpha} \pi 0 \sigma \tau \alpha \dot{\tau} \tau n \varsigma$ are both frequent metonymies of the devil, though they are not usually connected. As Charon equals Death, these two characters parallel the two infernal figures, who feature in the Gospel of Nicodemus and other dramatized representations of the descent (MacCulloch 1930, 227-33). The verb $\kappa \alpha \tau \alpha \delta \varepsilon \dot{\varepsilon} \omega$ has, besides the aforementioned rhetorical function, magical connotations as well.

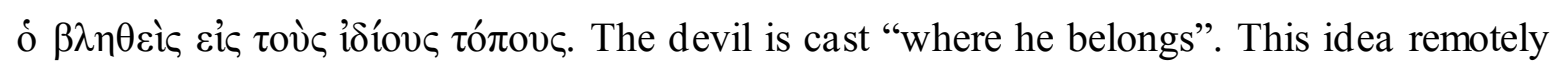
echoes Matt. 4:13, the end of the parable on the royal wedding. The rare expression iónovs

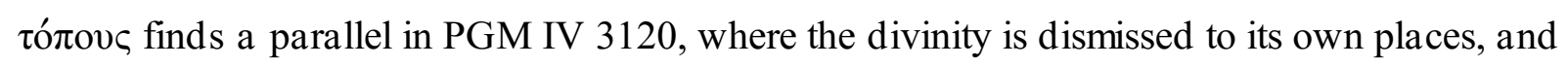


in the frequent adjurations of the divine 'by the places where you dwell' in the Coptic magical texts (Meyer and Smith 1994, No. 64, 79, 84, 98, 102, 103, 127, 134).

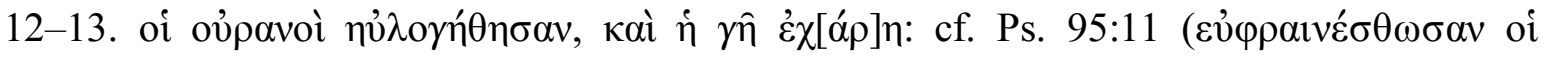

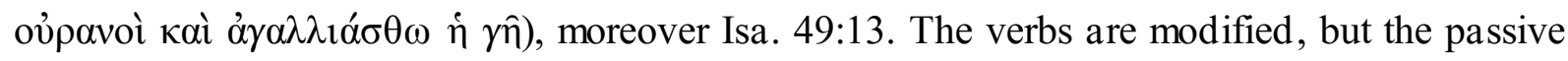

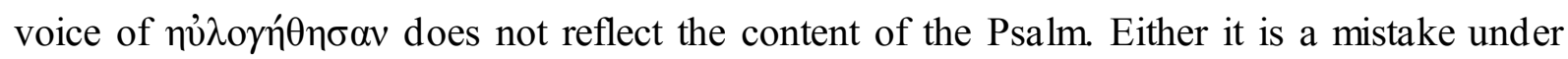
the influence of the medial of the Bible verse, or, less likely, the passive was meant, in this

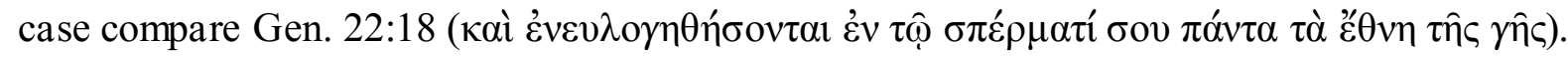

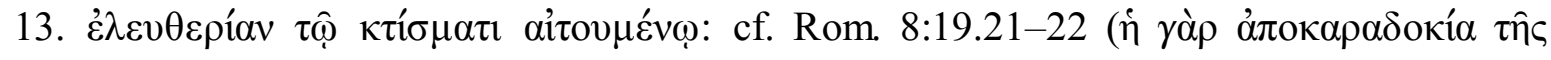

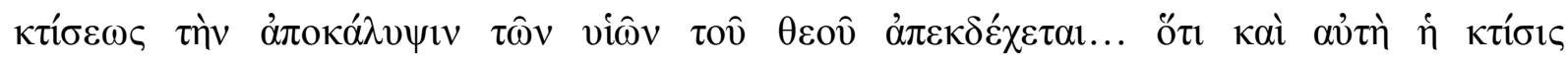

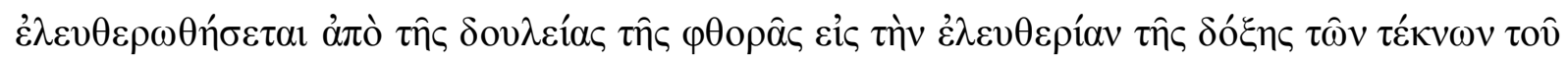

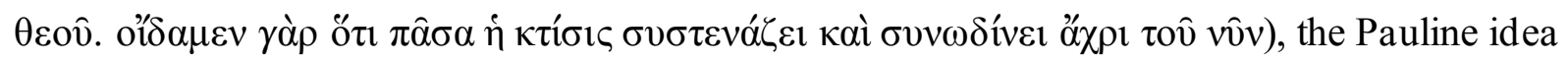
was contracted into a single clause. Alternatively, the $\kappa \tau i ́ \sigma \mu \alpha$ may refer to the person for whom the protection is asked, and the part following $\delta \varepsilon \sigma \pi$ ó $\eta v$ can be taken as a citation from him (Maravela 2014, 311).

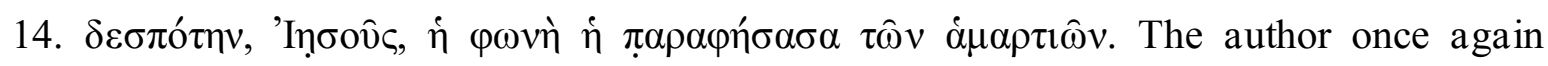
garbled the accusative and the nominative-vocative (unless 'I $\sigma 0 \hat{v} \varsigma$ starts a citation). The name 'Jesus' was postponed to the end of the invocation, while the Barcelona exorcism (P.Monts.Roca inv. 156a.8) and the exorcism of Severus of Antioch (PGM P12) begin with it. The name is unexpectedly not abbreviated as a nomen sacrum. $\pi \alpha \rho \alpha \varphi i ́ n \mu$ is a rare word. It means normally 'put out at the side' or 'discharge from service'; only in P.Laur. III 71 (98 AD) does it mean 'to remit'. The standard verb in this expression would be $\alpha$ áín $\mu$, which was exchanged here for a rare and strange variant.

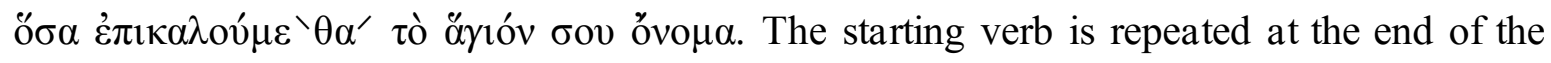
invocation, thus framing the text elegantly. The scribe originally wrote the active form, perhaps prompted by the more familiar $\pi \alpha \rho \alpha \kappa \alpha \lambda \circ \hat{v} \mu \varepsilon v$, but subsequently corrected it. The 
connection ő $\sigma \alpha$ remains problematic. Preisendanz corrects it into ö $\sigma o t$. However, the neutral of ö $\sigma \alpha$ could have been prompted by the reference to $\kappa \tau i ́ \sigma \mu \alpha$, while the plural by the first person plural of the verb, thus the correction may not be necessary, even if ö $\sigma \alpha$ is strange in this situation. The formulation of PGM P5b.51-53, where the request for healing is justified

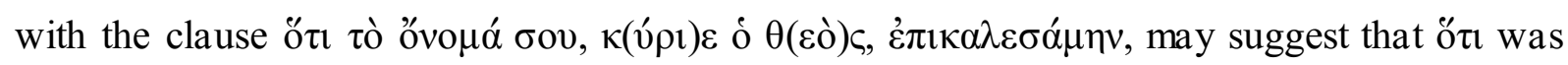
intended. However, corruption of ö $₫$ into ö $\sigma \alpha$ is difficult. Brashear and Kotansky $(2002,13)$ try to understand this and the previous clause as a 'liturgical response', similar to the ones they attempt to identify in P.Berol. 17202, an exorcistic text based on hymns. However, this interpretation is not convincing, as the clause is organic within the text, even if grammatical confusion garbles the structure.

15-17. These lines are part of a structure frequent both in magical $1^{12}$ and in liturgical ${ }^{13}$ texts, which can be termed 'catalogue of possible evils'. These lists occur predominantly in texts connected to the repulsion of demons (protective amulets, liturgical exorcisms, or prayers over the sick) and enumerate various kinds of mischief, against which they ask for protection or from which they ask for healing. They are present in pagan ritual texts (e.g. Suppl. Mag. I 6 (Roman period), including funeral texts [Smith 2009, 24]), and look back on traditional Egyptian practices (cf. Frankfurter 1998, 260). The 'possible evils' usually fall into three major categories: demonic forces, illnesses, and malignant human activity (often termed as $\mu \alpha \gamma^{\prime} \alpha$, , $\alpha \rho \mu \alpha \kappa i ́ \alpha$, or $\left.\beta \alpha \sigma \kappa \alpha v^{\prime} \alpha\right)$; in the liturgical texts idolatry may be added. Creating lists of possible evils could have been envisioned as a means of gaining control over them (Brakke 2006, 70).

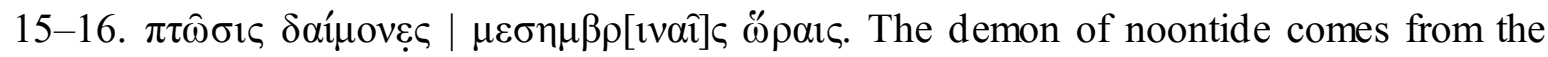
Septuagint text of Ps. 90:6 ( $\sigma \nu \mu \pi \tau \omega ́ \mu \alpha \tau o \varsigma ~ \delta \alpha \iota \mu$ ovíov $\mu \varepsilon \sigma \eta \mu \beta \rho ı v o v)$, and is a popular figure of Christian demonology (Lampe 1961, 845). The Biblical expression was altered. The primary meaning of $\pi \tau \hat{\omega} \sigma \imath \varsigma$ is 'fall' or 'casus', although it can also mean 'attack' in later Greek (SB 24 
15969 (491-518, бú $\mu \pi \tau \omega \sigma \iota \varsigma)) . \varepsilon /$ o interchange in unstressed syllable is frequent in the papyri (cf. Gignac 1976, 291-292).

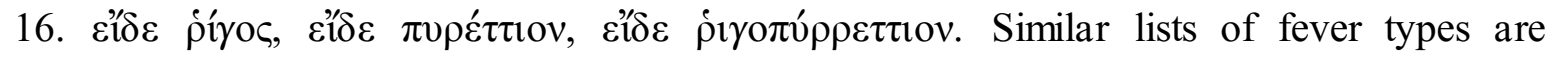
customary in fever amulets and other magical texts, both pagan and Christian, see De Haro Sanchez 2010.

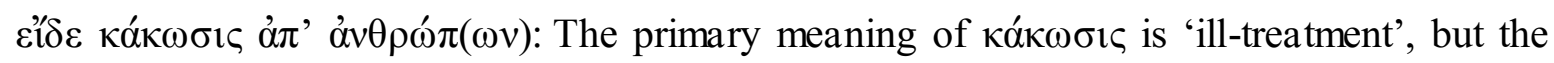
usual logic of the 'catalogues of possible evil' can suggest to understand it as malignant supernatural activity coming from people, as 'magic'.

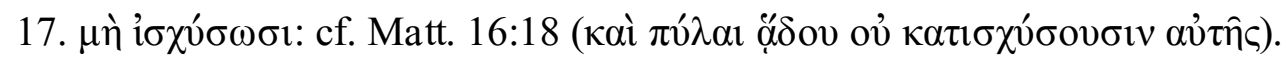

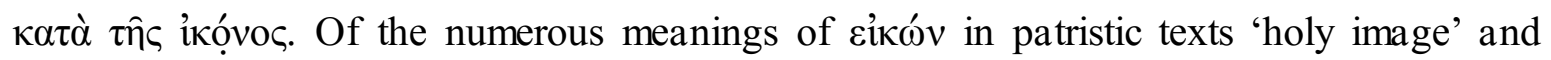
'image of God in man' (Lampe 1961, 411 and 413) are relevant here. Even though the latter usually stands with the specification $\tau 0 \hat{v} \theta \varepsilon \circ \hat{v}$, it is the more likely interpretation. As the text asks for protection among others from fever, it is hardly plausible that the object of that protection is a sacred image. Such an image could possibly have been consecrated by this prayer in order to serve as an amulet, but no reference to such a scenario can be found in the text. On the contrary, the protection is asked directly for the image, which is moreover presented as made by God's hand. This can rather be taken as a reference to the creation of

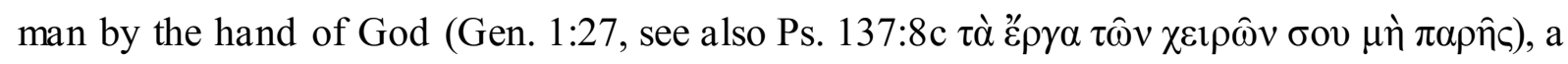

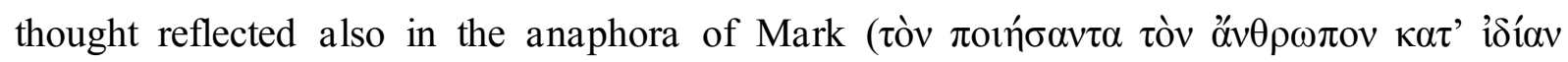

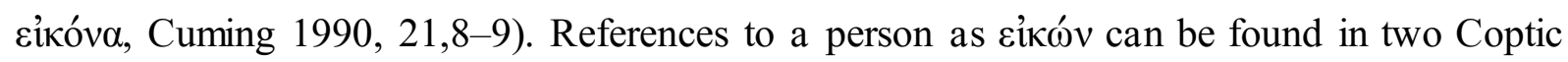
magical texts (Meyer and Smith, 1994 No. 135 (10 ${ }^{\text {th }}$ cent.) and P.Baden V $123\left(10-11^{\text {th }}\right.$ cent.)) and in a poem by Dioscorus of Aphrodito (P.Aphrod.Lit. 33.23), while an amulet (Suppl. Mag. I 24 (5 $5^{\text {th }}$ cent.)) and a prayer (P.DeirBala'izah fol. I v20) refer to a person as $\pi \lambda \alpha ́ \sigma \mu \alpha \theta(\varepsilon 0) \hat{v}$. 


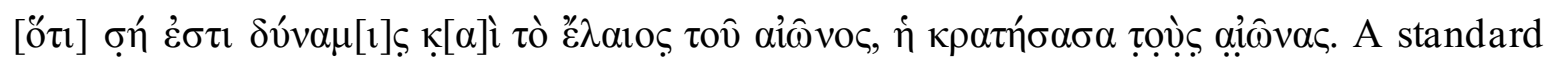

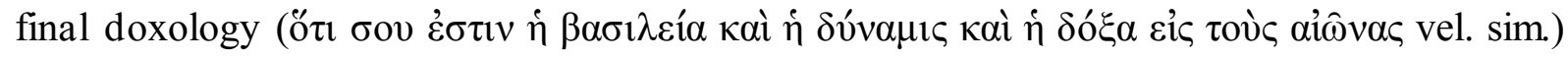
has been adjusted to the style and the wording of the prayer. The most important and default

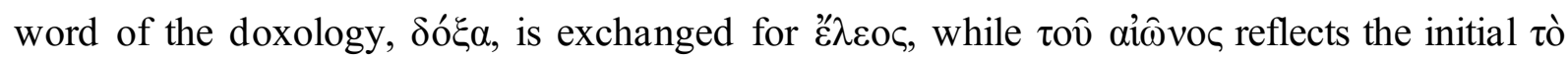

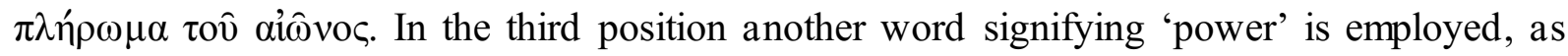
the author and user of the text needed the power of Jesus, not his glory. It was converted into

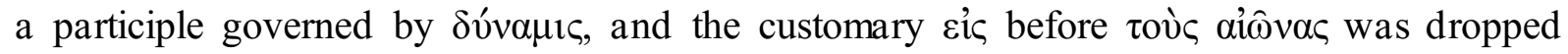
(perhaps accidentally).

\section{Discussion}

The prayer starts with an invocation of Jesus followed by a compressed account in participle form of the main events of his life. Similar concatenations are well known from the second article of the various creeds and have been termed the 'christological kerygma' (Kelly [1960] 1979, 17-18). This pattern has an enduring tradition in exorcistic texts from the $2^{\text {nd }}$ century with Justin the Martyr (Dial. 85:2) up to the late Byzantine magical formularies (e.g. Vassiliev 1893, 339). In Egypt it is shared by PGM P13 and P.Monts.Roca 156 a.6-b.3. A very short version is included in the prayer for oil of the sick (prayer no. 17) of the Euchologium of Sarapion (Johnson 1995, 66) after the mention of Jesus' name. There are moreover three amulets from the late antique Egypt as well, the so-called creedal amulets, which present an abridged version of Jesus' life in a series of short statements as the basis of their request: Suppl. Mag. I 23 ( $5^{\text {th }}$ cent.), 31 (5-6 $6^{\text {th }}$ cent.) and 35 ( $6^{\text {th }}$ cent.); for an analysis of these see NewDocs 3 114-118. There can have been multiple reasons why the story of Jesus' life was

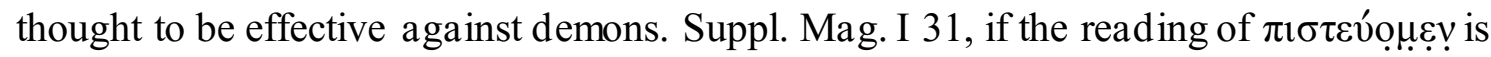
correct in 1. 2, bases the request on the analogy between the faith of the supplicants and the important role faith plays in New Testament healing stories (e.g. Mark 1:40, 2:5, Luke 8:48). 
A creed-like enumeration could efficiently strengthen the argument of faith. Suppl. Mag. I 23

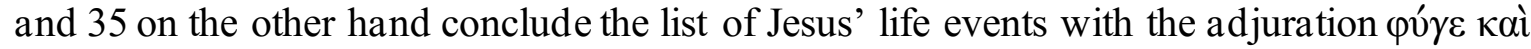

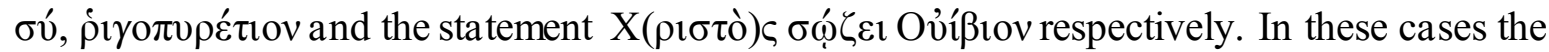
summaries of Jesus' life behave like the most powerful historiola (on the term, cf. Frankfurter [1995] 2001), as Jesus' life and death brought about the ultimate victory over demons. In PGM P13, there is no clear indication which function the narrative played, but the emphasis on Jesus' victory suggests that it was envisioned as a kind of historiola, the mythical and ultimate defeat of the evil powers being a basis for the request for protection (Maravela 2014, $310)$.

PGM P13 and the Barcelona exorcism agree in adding extra elements to the usual wording of the 'christological kerygma' as found in the creeds and other texts. Such are the mention of Bethlehem, Nazareth and Galilee in PGM P13, or the emperor Tiberius in the Barcelona exorcism. The most remarkable of all extensions in PGM P13 is the long description of Jesus' descent to the underworld in 11. 10-12. It is emphatically placed at the end of the invocation, inverting the order of the events, as it creates the ultimate basis for the request by describing the final victory of Jesus over the powers of evil. The doctrine of the descensus was by the late $4^{\text {th }}$ century a theological commonplace. Its factuality was not contested; only the details could be a matter of discussion (Gounelle 2000,141 ). It was since the $4^{\text {th }}$ century most commonly interpreted as Christ's definite victory over the evil forces (Gounelle 2000, 17), although in earlier thought the image of Christ preaching the Gospel to those in the underworld was equally popular (MacCulloch 1930, 241). By the middle of the $4^{\text {th }}$ century, the doctrine entered synodal creeds (the 'dated' creed of Sirmium (359), the creed of Nike (359) and of Constantinople (360), cf. Gounelle 2000, 257-319). By the $6^{\text {th }}$ century references to it became stereotyped (Gounelle 2000, 20). Of the various summaries of Christ's life in Greek from Egypt, i.e. the personal creeds of Alexander, Arius and Macarius (Kelly [1960] 
1979, 188-191), the idiosyncratic $12^{\text {th }}$ century Greek creed from Old Dongola in Nubia (Jakobielski and Łajtar, 1997), and the aforementioned exorcistic texts, only the Barcelona exorcism refers, though obscurely, to the descent (11. 15-16), in this case at the correct place between death and resurrection. It is on the other hand present in a summary of Jesus' life in the Sahidic Discourse on Abbaton by Timothy the Archbishop, where it follows the reference to the resurrection (Wallis Budge 1914, 238-240 and487-488). A similar summary in the aforementioned (comm. to 1. 2) fraction prayer of the Great Euchologium of the White Monastery p. 181 (Lanne 1958, 368-369), of which only the second part is preserved, starts with the descent, followed by resurrection, ascension and Christi cathedra. Its description of the descent has much in common with PGM P13. In PGM P13, it is presented mainly through a series of modified and merged Bible quotations: Ps. 106:16, Job 38:17, Ps. 106:10/ Isa. 42:7 and Matt. 12:29b (=Mark 3:27b). Of these, Ps. 106:16 is cited in the fraction prayer as well, while Ps. 106:10/ Isa. 42:7 and Matt. 12:29b (=Mark 3:27b) are alluded to. The exegesis of these Biblical quotations served in patristic writings often as the Scriptural basis for the doctrine of the descent, and they were, together with Ps. 23:7-10, the ones most frequently evoked to portray it (Bauckham 1998, 42). The Barcelona exorcism also employs a Scriptural quotation in its description of the descent (Ps. 17:6 in 1. 16). But while in the Barcelona exorcism the Biblical phrase remains a simple allusion, PGM P13 and the White Monastery fraction prayer knit more citations together into coherent and similar narratives: the gates are opened and the bars are shattered, the captives are freed, death is defeated and the devil is bound and cast down. The Gospel of Nicodemus exhibits a similar principle of narrating the descent on the basis of Bible verses, thereby providing a kind of narrative exegesis to them. The resulting story is quite similar, though it places Ps. 23:7-10 in its centre, which is missing from our texts. In the apocryphal work the citations only structure a much longer narrative, and they appear dramatized, uttered by the various Old Testament saints, the authors of these 
quotations, and by other characters. PGM P13 on the other hand constructs a short narrative from the quotations themselves. Only two extra clauses are inserted into the sequence of

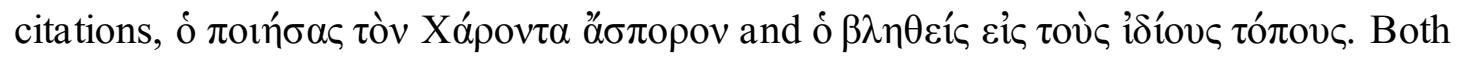
additions served to emphasize the complete defeat of the demonic forces, which is the main message of the narrative.

The last feature of PGM P13 to discuss is its idiosyncratic style. This is most evident in how it treats the Biblical and other sources. Goodspeed noted that the prayer 'is little more than a patchwork of biblical quotations, though these are sometimes very freely hand led' (Goodspeed 1901, 310-311). Upon close reading the free handling is revealed to be a systematic alteration of every Scriptural quotation (and also of the other sources employed). Only the citation of Eph. 6:12 in 1.15 remains intact except for the changes necessary to fit it into the grammatical structure. In all other cases words or expressions are exchanged, singular is employed instead of plural, verses are merged. The modifications can reflect a more classical choice of words as in 1.8 ( $\pi \tau \varepsilon \rho o ̀ v$ for $\pi \tau \dot{\varepsilon} \rho v \xi)$, but usually they do not, and they can also cause confusions in syntax as in 1.11 . Sometimes they may be explained as inaccurate citations by memory, but others, such as $11.1,2-3,4-5,7,8-9,10,14,15-16$ cannot. In general, there seems to be a deliberate variation with no other overall principle than variation itself. This suggests a connection with an antique form of rhetorical exercise, the paraphrase, 'a literary game suitable for all ages' (Miguélez Cavero 2008, 309), where the principle is to change 'the form of expression while keeping the thoughts themselves' (Progymnasmata of Theon 15, ed. Patillon and Bolognesi, 107). The author of the PGM P13 seems to have employed a rhetorical technique learnt at school to enhance the efficacy of his text. The text exhibits other rhetorical features as well, such as the reversal of the natural order of the events death-descent-ascension to place the descent at the end or the triple repetition of the verbal prefix $\kappa \alpha \tau \alpha-$ to express the totality of Jesus' victory $(1.2,10,12)$. These observations give us 
the outlines of an author who was consciously using rhetorical techniques, though not on a very high level, and who was eager to exhibit a certain culture, even if his efforts occasionally resulted in garbled or clumsy wordings.

The application of Charon's name for death fits very well this general character of the text. As we have seen in the commentary to 1.2 , the name of Charon was not a commonplace in Hellenized Egypt. The author of PGM P13 probably picked this name for death due to its sophisticated air, while he could have been prompted by the existing equation of Charon with death itself. With this word he could give both an exotic and learned ring to his prayer.

PGM P13 reveals an author who endeavoured to create a text that sounded unusual and sophisticated, in spite of its errors. These efforts find a parallel in the eagerness to exhibit culture and employ rhetoric in order to ensure success, be it in the case of actual petitions or in more general terms of status or career, which characterizes the oeuvre of Dioscorus of Aphrodito. This effort can be observed in several features such as in the use of accents in his copies, in his rhetorically composed petitions, or in his production of encomiastic poetry, cf. P.Aphrod.Lit. p. 683-687. Dioscorus' technique of exhibiting culture to ensure efficacy was not limited to the affairs of this world. PGM P13a, a draft of an amulet in Dioscorus' hand, with its Homeric-flavoured coinages applied the same principle to the communication with the supernatural in order to lend efficacy to a protective text.

The author of PGM P13 apparently did the same. To achieve his goal, he employed various strategies: rhetoric; techniques learnt at school; Hellenising elements, or motives of Gnostic flavour as the emphasis on the role of Gabriel (see commentary to 1. 2), or the recurring $\alpha i \omega v$ in singular. However, even with the Gnostic and the pagan elements, he stayed within the interpretative frameworks Christianity, as Barbel([1941] 1964, 253) observed. Where he employed elements extraneous to the Christian tradition, he accommodated them to it. This happened with the Gnosticizing Gabriel as well as with Charon: the ferryman of the Greek 
underworld, the most pronounced testimony to the author's Hellenic culture denotes death, a demonic power which Jesus defeats. By merging and accommodating all these external elements into a Christian world, PGM P13 can even be read as celebrating Jesus' and thereby Christianity's victory over the competing religious traditions. Thus, PGM P13 witnesses only to a limited extent A. Scibilia's 'ritual contamination' (Scibilia 2008, 179). The elements of competing religious traditions do not reflect the author's actual beliefs in Charon or in the Gnostic aion or 'highest aionic entity' (182). The historiola, the 'mythic' episodes the power of which is activated through the narrative, does not rely on their potential, but on that of the victorious Son of God. Charon and the others are harmless rhetorical elements, which serve only to add an idiosyncratic touch to the text, and thereby enhance its efficacy, in a world where rhetoric and sophisticated self-expression were conceived as the key to the success of a text and its author.

\footnotetext{
${ }^{1}$ This article owes much to the suggestions and ideas of Anastasia Maravela, Árpárd M. Nagy, Sofia Torallas Tovar, Silvio Bär, Cornelia Römer, Hermann Harrauer and Gábor Bolonyai, to whom I am grateful for reading the different redactions. The paper is a developed English version of a Master's thesis in Hungarian supervised by László Horváth and defended at the University of Budapest in 2014.

2 The text was also shortly discussed by J. Barbel ([1941] 1964, 253) by Brashear and Kotanski 2002, and by Maravela 2014.

${ }^{3}$ Accessible at http://www.trismegistos.org/ldab/search.php by searching the LDAB number 5787 (accessed 26/01/2015).

${ }^{4}$ On recognizing text-carrying objects as amulets, see De Bruyn 2010, 149-161.

${ }^{5}$ For the influence of Egyptian on Greek in Egypt see Clackson 2010, 79-82 and Vierros 2012, especially 105-117 and 147-154 for the phenomena in PGM P13.

${ }^{6}$ On similar cas es of semantic borrowing, where the multiple meaning of the Egyptian counterpart allows for the development of a new significance in Greek, see Torallas Tovar 2004171.

7 The third volume of Preisendanz's Papyri Graecae Magicae, which contains the Indices, was never published due to the Second World War. Photocopies of page proofs are available in several libraries.

${ }^{8}$ I thank Lajos Berkes for sharing his draft edition of the inscription with me.

${ }^{9}$ A typical example of this tendency is P.Mon.Epiph. $49\left(6-7^{\text {th }}\right.$ cent.), where a sequence of creedal statements on Christ are translated into Coptic. While every translation is literal, the reference to the ascension, $\theta(\varepsilon \dot{)}) \varsigma$

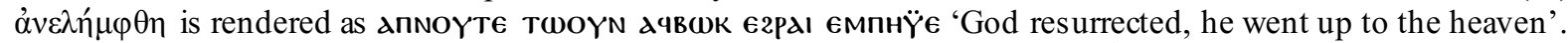

10 The Jewish apocryphon was read in Egypt as it was discovered on a $4^{\text {th }}$ century papyrus (Black 1970 7), and cited by Origen (Cels. V 52).

${ }^{11}$ I owe both the reading and the parallel to Sofia Torallas Tovar.

12 Meyer 1996 4.1-25, 10,10-17, Meyer and Smith 1994 No. 61 (only magia), 62, 63 (8-9 ${ }^{\text {th }}$ cent.), 64, 71 (only demons), $132\left(6-7^{\text {th }}\right.$ cent.), 134,135 (10 ${ }^{\text {th }}$ cent.), PGM P3 (4-5 $5^{\text {th }}$ cent.), P9 $\left(6^{\text {th }}\right.$ cent.), P13a (6-7 $7^{\text {th }}$ cent., only demons), P17 (5-6 ${ }^{\text {th }}$ cent., only demons), P21 (ca. 300), Suppl. Mag. I 31 ( $6^{\text {th }}$ cent.), II 84 (3-4 ${ }^{\text {th }}$ cent.).

${ }^{13} \mathrm{Eg}$. a short version in the prayer of the laying on of the hands from the Barcelona codex (P.Monts.Roca inv. 155 b.23-24, see Römer, Daniel, and Worp 1997, 131, in the Barcelona exorcism (P.Monts.Roca inv. 156 a.2124 ), in the consecration of the oil of the sick in the euchologium of Sarapion (Johnson 1995, 66); also in a number of consecratory prayers (Burmester 1967, 115 (exorcism and consecration of the baptismal oil), 233 (of the kallielaion)), and in the first prayer of the morning offering of incense (Bute 1882, 5).
} 


\section{References}

Barbel, J. (1941) 1964. Christos Angelos. Die Anschauung von Christus als Bote und Engel in der gelehrten und volkstümlichen Literatur des christlichen Altertums. Bonn: Peter Hanstein.

Bauckham, R. 1998. The Fate of the Dead. Studies on the Jewish and Christian Apocalypses. Leiden: Brill.

Betz, H. D., ed. 1986. The Greek Magical Papyri in Translation Including the Demotic Spells. Chicago: University of Chicago Press.

Black, M., ed. 1970. “Apocalypsis Henochi Graece.” In Pseudoepigrapha Veteris Testamenti Graece. Vol. III., edited by A. M. Denis and M. De Jonge, 1-44. Leiden: Brill.

Brakke, D. 2006. Demons and the Making of the Monk. Spiritual Combat in Early Christianity. Cambridge, MA: Harvard University Press.

Brashear, W. and Kotansky, R. 2002. "A New Magical Formulary.” In Magic and Ritual in the Ancient World, edited by P. Mirecki and M. Meyer. Leiden: Brill.

Brightman, F. E. (1896) 2002. Eastern Liturgies Being the Texts Original or Translated of the Principal Liturgies of the Church. Reprint, Piscataway NJ: Gorgias Press.

Burmester, O.H.E. KHS. 1967. The Egyptian or Coptic Chruch. A Detailed Description of Her Liturgical Services and the Rites and Ceremonies Observed in the Administration of Her Sacraments. Le Caire.

Bute, J. P. 1882. The Coptic Morning Service for the Lord's Day. London: J. Masters \& Co.

Cuming, G. J. 1990. The Liturgy of St Mark. Rome: Pontificium Institutum Studiorum Orientalium.

Clackson, S. J. 2010. "Coptic or Greek? Bilingualism in the Papyi." In The Multilingual Experience in Egypt, from the Ptolemies to the Abbasids, edited by A. Papaconstantinou, 73-104. Farnham: Ashgate. 
De Bruyn, T. 2010. 'Papyri, Parchments, Ostraca, and Tablets Written with Biblical Texts in Greek and Used as Amulets: A Preliminary List." In Early Christian Manuscripts: Examples of Applied Method and Approach, edited by T.J. Kraus and T. Nicklas, 145-189. Leiden: Brill.

De Haro Sanchez, M. 2010. "La vocabulaire de la pathologie et de a thérapeutique dans les papyrus iatromagiques grecs. Fiévres, traumatismes et épilepsie.” Bulletin of the Americal Society of Papyrologists 47: 131-153.

Förster, H. 1997. 'Das angeblich älteste liturgische Schriftstück. Neuedition von P.Vindob. G 2326", Zeitschrift für Antike und Christentum 1:169-177.

Frankfurter, D. 1998. Religion in Roman Egypt. Assimilation and Resistance. Princeton, N.J.: Princeton University Press.

Frankfurter, D. (1995) 2001. "Narrating Power: The Theory and Practice of the Magical Historiola in Ritual Spells." In Ancient Magic and Ritual Power, edited by M. Meyer and P. Mirecki, 457-476. Boston: Brill.

Frankfurter, D. 2013. "Amente Demons and Christian syncretism." Archiv für Religionsgeschichte 14: 93-101.

Gerhards, A. 1984. Die griechische Gregoriosanaphora. Ein beitrag zur Geschichte des eucharistischen Hochgebets. Münster Westfalen: Aschendorff.

Gignac 1976. Phonology. Vol. I of A Grammar of the Greek Papyri of the Roman and Byzantine Periods. Milan: Istituto Editoriale Cisalpino -La Goliardica.

Goodspeed, E. J. 1901. “An Early Christian Prayer.” The Biblical World 17: 309-311.

Gounelle, R. 2000. La descente du Christ aux enfers. Institutionnalisation d'une croyance. Paris: Institut d'Études Augustiniennes.

Gounelle, R. 2006. 'L'enfer selon l'Évangile de Nicodème.” Revue d'histoire et de philosophie religieuses 86: 313-333. 
Henner, J. 2000. Fragmenta Liturgica Coptica. Editionen und Kommentar liturgischer Texte der Koptischen Kirche des ersten Jahrhunderts. Tübingen: Mohr Siebeck.

Jacoby, A. 1900. Ein neues Evangelienfragment. Strassburg: Karl J. Tübner.

Jakobielski, S. and A. Łajtar. 1997. "Ein Glaubensbekenntnis aus Alt Dongola (Sudan).” Journal of Juristic Papyrology 27: 7-26.

Johnson, M. E. 1995. The Prayers of Sarapion of Thmuis. A Literary, Liturgical, and Theological Analysis. Rome: Pontificio Istituto Orientale.

Jungmann, J. A. (1925) 1962. Die Stellung Christi im liturgischen Gebet. Second edition, Münster Westfalen: Aschendorff.

Kattenbusch, F. 1894. Das apostolische Symbol. Seine Entstehung, sein geschichtlicher Sinn, seine Ursprüngliche Stellung im Kultus und in der Theologie der Kirche. Leipzig: J. C. Hinrischs'sche Buchhandlung.

Kelly, J. N. D. (1960) 1979. Early Christian Creeds. Third edition, London: Longman.

Kotansky, R. 1995. "Remnants of a Liturgical Exorcism on a Gem." Le Muséon 108: 143156.

Lampe, G. W. H., ed. 1961. A Patristic Greek Lexicon. Oxford: Clarendon Press.

Lanne, E. 1958. Le Grand Euchologe du Monastère Blanc. PO XXVIII/2. Turnhout: Brepols.

Lanne, E. 1979. "La confession de la foi baptismale á Alexandrie et a Rome.” In La liturgie expression de la foi. Conférences Saint-Serge XXV semaine d'études liturgiques, edited by A. M. Triacca and A. Pistoia, 213-228. Rome: C.L.V. Edizioni Liturgiche.

MacCown, Ch. Ch. 1922. The Testament of Solomon Edited from Manuscripts at Mount Athos, Bologna, Holkhalm Hall, Jerusalem, London, Milan, Paris and Vienna. Leipzig: J. C. Hinrischs'sche Buchhandlung.

MacCullogh, J. A. 1930. The Harrowing of Hell. A Comparative Study of an Early Christian Doctrine. Edinburgh: T. \& T. Clark. 
Maltomini, F. 1982. “Cristo all'Eufrate. P.Heid. G 1101: Amuleto Cristiano.” Zeitschrift für Papyrologie und Epigraphik 48:149-170.

Maravela, A. 2014. "Christians Praying in a Graeco-Egyptian Context: Intimations of Christian Identity in Greek Papyrus Prayers." In Prayer and Identity Formation in Early Christianity, edited by R. Hvalvik and K. O. Sandnes, 291-323. Tübingen: Mohr Siebeck.

Meyer, M. 1996. The Magical Book of Mary and the Angels (P.Heid. Inv. Kopt. 685). Heidelberg: Univers itätsverlag Winter.

Meyer, M. and R. Smith, eds. 1994. Ancient Christian Magic: Coptic Texts of Ritual Power. Princeton, N.J.: Princeton University Press.

Miguélez Cavero, L. 2008. Poems in Context: Greek Poetry in the Egyptian Thebaid 200-600 $A D$. Berlin: de Gruyter.

Patillon, M. and G. Bolognesi. 1997. Aelius Théon, Progymnasmata. Paris: Les Belles Lettres. Preisendanz, K. 1931. Papyri Graecae Magicae. Die griechischen Zauberpapyri Vol II of Papyri Graecae Magicae. Die griechischen Zauberpapyri. 1930-1931. Leipzig: Teubner.

Preisendanz, K. and A. Henrichs. 1972-74. Papyri Graecae Magicae. Die griechischen Zauberpapyri. Zweite, verbesserte Auflage. (PGM) 2 Vol. Stuttgart: Teubner.

Roberts, C. H. and B. Capelle. 1949. An Early Euchologium: The Der-Balizeh Papyrus enlarged and re-edited. Louvain: Bureaux Du Muséon.

Roca-Puig, R. 1994. Anàfora de Barcelona i altres pregàries. (Missa del segle IV). Barcelona.

Römer, C., R. W. Daniel, and K. A. Worp. 1997. 'Das Gebet zur Handauflegung bei Kranken in P.Barc. 155,19 -156, 5 und P.Kellis I 88." Zeitschrift für Papyrologie und Epigraphik 119: $128-131$.

Schmidt, C. 1905. Koptisch-Gnostische Schriften. Band I. Leipzig. 
Schmidt, C. 1914. "Zwei altchristliche Gebete.” In Neutestamentliche Studien Georg Henrici zu seinem 70. Geburtstag, 66-78. Leipzig: J. C. Hinrich'sche Buchhandlung.

Scibilia, A. 2008. 'Un invocazione greca proveniente dall' Egitto cristiano. Il Papiro Kairo 10263 ed un procedimento di cristianizzazione." In Cristo e Asclepio. Culti terapeutici e taumaturgici nel mondo mediterraneo antico fra cristiani e pagani. Atti del convegno internazionale, Accademia di studi mediterranei, Agrigento 20-21 novembre 2006, edited by E. Dal Covolo and G. Sfameni Gasparro, 176-182. Roma: Libreria Ateneo Silesiano.

Smith, M., ed. 2009. Traversing Eternity: texts for the afterlife from Ptolemaic and Roman Egypt. Oxford: Oxford University Press.

Stadler, M. A., 2012. "Funerary Religion." In The Oxford Handbook of Roman Egypt, edited by C. Riggs, 383-397. Oxford: Oxford University Press.

Suciu, A. 2011. "À propos de la datation du manuscrit contenant le Grand Euchologe du Monastère Blanc.” In Vigiliae Christianae 65:189-198.

Thompson, H. 1932. The Coptic Version of the Acts of the Apostles and the Pauline Letters in Sahidic Dialect. Cambridge: University Press.

Torallas Tovar, S. 2004. "Egyptian Lexical Interference in the Greek of Byzantine and Early Islamic Egypt." In Papyrology and the History of Early Islamic Egypt, edited by P. Sijpestijn and L. Sundelin, 163-198. Leiden: Brill.

Vassiliev, A. 1893. Anecdota Graeco-Byzantina Vol. I. Mosquae.

Vierros, M. 2012. Bilingual Notaries in Hellenistic Egypt. A Study of Greek as a Second Language. Brussel: Koninklijke Vlaamse Academie van België voor Wetenschappen en Kunsten.

Wallis Budge, E. A. 1913. Coptic Apocrypha in the Dialect of Upper Egypt. London.

Wallis Budge, E. A. 1914. Coptic Martyrdoms in the Dialect of Upper Egypt. London. 
Wallis Budge, E. A. 1915. Miscellaneous Coptic Texts in the Dialect of Upper Egypt. London.

Walters, C. C. 1989: “Christian paintings from Tebtynis.” Journal of Egyptian Archaeology 75: 191-208.

Waser, O. 1898. Charon, Charun, Charos. Mythologisch-archäologische Monographie. Berlin: Weidmannsche Buchhandlung.

Wright, J. E. 2000. The early history of heaven. New York: Oxford University Press.

Zandee, J. 1960. Death as an Enemy, According to Ancient Egyptian Conceptions. Leiden: Brill.

Zheltov, M. 2008. "The Anaphora and the Thanksgiving Prayer from the Barcelona Papyrus: An Underestimated Testimony to the Anaphoral History in the Fourth Century" Vigiliae Christianae 62: 467-504. 